\title{
High methylation of the 4-aminobutyrate aminotransferase gene predicts a poor prognosis in patients with myelodysplastic syndrome
}

\author{
GUANGJIE ZHAO ${ }^{1}$, NIANYI LI ${ }^{1}$, SHUANG LI ${ }^{1}$, WANLING WU ${ }^{1}$, XIAOQIN WANG ${ }^{1}$ and JINGWEN GU ${ }^{2}$ \\ ${ }^{1}$ Department of Haematology, ${ }^{2}$ Worldwide Medical Center, \\ Huashan Hospital of Fudan University, Shanghai 200040, P.R. China
}

Received July 17, 2018; Accepted November 2, 2018

DOI: $10.3892 / \mathrm{ijo} .2018 .4652$

\begin{abstract}
In our previous study, the 4-aminobutyrate aminotransferase $(A B A T)$ gene was screened and selected as a target gene that may affect the prognosis of myelodysplastic syndrome (MDS). The present study aimed to determine the prognostic value of $A B A T$ in 152 patients with MDS, 29 patients with acute myeloid leukemia (AML) and 40 controls, by detecting the expression and methylation levels of the $A B A T$ gene. In patients with MDS, the expression levels of $A B A T$ were significantly reduced compared with in the controls $(\mathrm{P}<0.0001)$, and the degree of DNA methylation was increased in MDS subjects $(\mathrm{P}<0.0001)$. Age, hemoglobin level, marrow blasts, International Prognostic Scoring System karyotype, and the expression and methylation levels of $A B A T$ were associated with overall survival (OS), as determined by univariate analysis. Multivariate analysis revealed that older age, higher marrow blasts and higher methylation percentage were independent risk factors for OS. In addition, a functional study demonstrated that $A B A T$ gene silencing increased cell apoptosis and blocked the $\mathrm{G}_{1} / \mathrm{S}$ phase in SKM-1 and THP-1 human leukemia cells. A $\gamma$-aminobutyrate aminotransferase inhibitor also blocked the $G_{1} / S$ phase; however, it had no effect on cell apoptosis. In conclusion, the present study demonstrated that $A B A T$ methylation served an essential role in the progression of MDS and therefore may be considered an indicator of poor prognosis for hematological malignancies.
\end{abstract}

Correspondence to: Dr Jingwen Gu, Worldwide Medical Center, Huashan Hospital of Fudan University, 12 Wulumuqi Road Central, Shanghai 200040, P.R. China

E-mail: jingwengu5288@163.com

Dr Xiaoqin Wang, Department of Haematology, Huashan Hospital of Fudan University, 12 Wulumuqi Road Central, Shanghai 200040, P.R. China

E-mail: wangxiaoqin@shmu.edu.cn

Key words: ABAT gene, DNA methylation, overall survival, myelodysplastic syndrome

\section{Introduction}

Myelodysplastic syndrome (MDS) is a heterogeneous hematopoietic malignancy that is characterized by ineffective hematopoiesis, and is accompanied by abnormal maturation and dysplasia in one or more blood cell lineages (1). The pathogenesis of MDS is currently unclear; however, it has been reported to be associated with gene mutations, immune dysregulation, chromosomal abnormalities, epigenetic abnormalities and other factors. DNA methylation is an important research topic in epigenetics, which has been demonstrated to be involved in the development and progression of MDS. In addition, it is a biomarker for the diagnosis, treatment and survival of patients with MDS (2-5).

In our previous study, six genes [4-aminobutyrate aminotransferase $(A B A T)$, dual adaptor of phosphotyrosine and 3-phosphoinositides 1, Fas-associated via death domain, LRR-binding FLII-interacting protein 1, phospholipase B domain-containing 1 and sphingomyelin phosphodiesterase 3] were screened out through genome-wide DNA methylation profiling and gene expression microarray in four patients with MDS and four controls (4). In addition, significant alterations have been observed in the expression levels of $A B A T$, as compared with other genes, after leukemia cell lines are treated with decitabine, which is a hypomethylating agent (6). Therefore, this gene was selected as a target gene.

$A B A T$ encodes $\gamma$-aminobutyrate aminotransferase (GABAT), which participates in catabolism of the inhibitory neurotransmitter $\gamma$-aminobutyric acid (GABA) (7). Recently, Besse et al reported an essential role for $A B A T$ in the mitochondrial nucleoside salvage pathway, which may facilitate the conversion of deoxyribonucleoside diphosphate into deoxyribonucleoside triphosphate, and maintain the function of the mitochondrial membrane (8). Furthermore, alterations in the expression levels of $A B A T$ take part in the development of breast cancer and hepatocellular carcinoma (9-11). However, to the best of our knowledge, no studies have focused on the pathogenic mechanisms and prognostic value of $A B A T$ in patients with MDS.

In the present study, the expression and methylation levels of $A B A T$ were detected in 152 patients with MDS, 29 patients with acute myeloid leukemia (AML) and 40 controls 
using reverse transcription-quantitative polymerase chain reaction (RT-qPCR) and methylation-sensitive high resolution melting (MS-HRM), respectively. The expression and methylation levels of $A B A T$ were found to be associated with overall survival (OS) in patients with MDS. In addition, cell viability, cell apoptosis and cell cycle progression were analyzed in leukemia cell lines with $A B A T$ gene silencing or in cell lines treated with a GABAT inhibitor, in order to demonstrate the role of $A B A T$ in the pathogenesis of MDS.

\section{Materials and methods}

Patients and bone marrow samples. Bone marrow samples were extracted from 152 adult patients with MDS and 29 patients with AML. All patients were diagnosed according to the 2008 World Health Organization (WHO) criteria (12). Of the patients with MDS, 92 were men and 60 were women, with a median age of 56 years (range, 18-86 years). A total of 84 patients had refractory cytopenia with multilineage dysplasia (RCMD), 8 had RCMD with ring sideroblasts (RCMD-RS), 17 had refractory anemia with an excess of blasts type 1 (RAEB-1), 29 had RAEB-2, five had refractory anemia (RA), two had refractory anemia with ring sideroblasts (RARS), six had an unclassifiable form of MDS (MDS-U) and one had 5q-syndrome. Of the patients with AML, 16 were diagnosed with acute myelomonocytic leukemia, six with acute monocytic leukemia (AML-M5) and seven with AML with mixed-lineage leukemia rearrangements. The prognostic score for each patient with MDS was calculated using the International Prognostic Scoring System (IPSS) (13). All subjects with MDS were recruited on January 1, 2008 by the Sino-U.S. Shanghai Leukemia Cooperative Group (School of Public Health, Fudan University, Shanghai, China), and were followed up until they succumbed to the disease or until the last follow-up date (December 30, 2015). Two subjects did not undergo chromosomal examination due to examination failure. Finally, 69 subjects succumbed and 14 subjects progressed to AML. In addition, bone marrow samples from 40 subjects without hematological malignancies were obtained between December 30, 2015 and January 1, 2018, and were analyzed as controls. The control subjects were diagnosed as having immune thrombocytopenia by bone marrow smears and chromosomal examinations. Subsequently, a 2-year follow-up period ensured that these controls did not develop MDS or other clonal disorders. No statistical difference was found with regards to age and sex among the subjects with MDS and AML and the controls. The present study was approved by the Ethics Committee of Huashan Hospital, Fudan University (approval no. KY2015-269; Shanghai, China), and informed consent was obtained from each participant.

$R N A$ isolation and $R T-q P C R$. The mononuclear cells were harvested by bone marrow aspiration and were isolated by centrifugation (600 x g for $20 \mathrm{~min}$ at room temperature) in lymphocyte separation medium $\left(\right.$ Ficoll ${ }^{\circledR}$ Paque Plus; GE Healthcare, Chicago, IL, USA). Total RNA was isolated from bone marrow mononuclear cells using the QIAamp RNA Blood Mini kit (Qiagen GmbH, Hilden, Germany). TRIzol ${ }^{\circledR}$ reagent (Invitrogen; Thermo Fisher Scientific, Inc.,
Waltham, MA, USA) was used to isolate total RNA from the cultured leukemia cells after culture medium was removed and the cells were washed with pre-cooled PBS $\left(4^{\circ} \mathrm{C}\right)$ three times. The purity of RNA was assessed by measuring the optical density (OD) 260/280 ratio using a NanoDrop spectrophotometer (NanoDrop Technologies; Thermo Fisher Scientific, Inc., Wilmington, DE, USA). The RNA samples were then reverse transcribed into cDNA using Takara PrimeScript RT Master Mix (Takara Bio, Inc., Otsu, Japan). The 10- $\mu$ l reaction mixture comprised $2 \mu 15 \mathrm{X}$ PrimeScript RT Master Mix, 500 ng RNA and RNase-Free distilled $\mathrm{H}_{2} \mathrm{O}$, which was used to ensure the total reached $10 \mu \mathrm{l}$. Subsequently, the mixture was amplified at $37^{\circ} \mathrm{C}$ for $15 \mathrm{~min}, 85^{\circ} \mathrm{C}$ for $5 \mathrm{sec}$ and was stored at $4^{\circ} \mathrm{C}$ for further use.

For RT-qPCR, cDNA samples were amplified using an ABI Prism 7500 Sequence Detection system (Applied Biosystems; Thermo Fisher Scientific, Inc.) with Takara SYBR Premix Ex Taq PCR reagents (Takara Bio, Inc.). A 20- $\mu$ l reaction mixture containing $10 \mu \mathrm{l}$ SYBR-Green premix, $0.4 \mu \mathrm{l}$ each primer $(10 \mu \mathrm{M}), 0.4 \mu 1$ ROX Reference Dye II, $2 \mu 1 \mathrm{cDNA}$ and $6.8 \mu \mathrm{l}$ DEPC-treated water was amplified at $95^{\circ} \mathrm{C}$ for $30 \mathrm{sec}$, followed by 40 cycles at $95^{\circ} \mathrm{C}$ for $5 \mathrm{sec}$ and $60^{\circ} \mathrm{C}$ for 34 sec. The PCR primer sequences for $A B A T$ were as follows: Forward, 5'-TTT TCTGTCTCCTCCACCTGTC-3' and reverse, 5'-CTGGCT GGGTTCATCCTAAG-3', which resulted in amplification of a 113-bp PCR band. The GAPDH primer sequences were as follows: Forward, 5'-TGGATGAAGTTGGTGGTGAG-3' and reverse, 5'-CAGCATCAGGAGTGGACAGA-3', which resulted in amplification of an 87-bp PCR band. The relative abundance of $A B A T$ mRNA was normalized to the levels of $G A P D H$ mRNA using the $2^{-\Delta \Delta \mathrm{Cq}}$ (fold change) method (14).

DNA isolation and MS-HRM. Total DNA was isolated from bone marrow mononuclear cells using QIAamp DNA Blood Mini kit (Qiagen $\mathrm{GmbH}$ ), according to the manufacturer's protocol. DNA quality and purity were assessed using the aforementioned methods, and DNA samples were stored at $-20^{\circ} \mathrm{C}$ for further use.

For MS-HRM, DNA samples from all patients, and human methylated and nonmethylated DNA standards (Zymo Research Corp., Irvine, CA, USA) were modified using the EZ DNA Methylation-Gold kit (Zymo Research Corp.), according to the manufacturer's protocol. In addition, the human methylated and nonmethylated DNA standards were mixed at a ratio of 1:9, 1:3, 1:1 and 3:1 to perform DNA methylation modification. All modified DNA samples were amplified using the C1000 Touch Thermal Cycler (Bio-Rad Laboratories, Inc.) with Takara Premix Taq Hot Start Version (Takara Bio, Inc.). A $25-\mu 1$ reaction mixture containing $12.5 \mu \mathrm{l}$ Premix Taq Hot Start Version, $1 \mu \mathrm{l}$ each primer $(10 \mu \mathrm{M}), 1 \mu \mathrm{l}$ modified DNA and $9.5 \mu \mathrm{l}$ DEPC-treated water was amplified at $95^{\circ} \mathrm{C}$ for $2 \mathrm{~min}$, followed by 40 cycles at $95^{\circ} \mathrm{C}$ for $30 \mathrm{sec}, 59^{\circ} \mathrm{C}$ for $30 \mathrm{sec}$ and $72^{\circ} \mathrm{C}$ for $30 \mathrm{sec}$, and an extension step at $72^{\circ} \mathrm{C}$ for $5 \mathrm{~min}$. Subsequently, the amplified product was added to $0.9 \mu 1$ SYTO 9 Green Fluorescent Nucleic Acid Stain (Invitrogen; Thermo Fisher Scientific, Inc.) and reacted at $94^{\circ} \mathrm{C}$ for $60 \mathrm{sec}$ and $40^{\circ} \mathrm{C}$ for $60 \mathrm{sec}$. Data were collected between $75^{\circ} \mathrm{C}$ and $85^{\circ} \mathrm{C}$ using Rotor Gene 6000 (Qiagen $\mathrm{GmbH}$ ). The methylation primers for $A B A T$ were as follows: Forward, 
5'-GTAAGAAGGGTTGGTAGGGTTTT-3' and reverse, 5'-ACCATTTACACCCTCAAAACTACA-3', which resulted in amplification of a 183-bp PCR band.

Cell culture and short hairpin (sh)RNA knockdown of ABAT. In the present study, SKM-1 and THP-1 leukemia cell lines were used. The SKM-1 cell line is derived from a patient with leukemia transformed from MDS; therefore, this cell line has similar characteristics to MDS. The THP-1 cell line is derived from a patient with AML-M5. Mutations in the ABAT gene were detected in both cell lines used in this study. The $A B A T$ gene mutations detected in the SKM-1 cell line were as follows: $309 \mathrm{C}>\mathrm{T}, \mathrm{V} 103 \mathrm{~V}$; $984 \mathrm{C}>\mathrm{A}, \mathrm{V} 328 \mathrm{~V}$ and $167 \mathrm{G}>\mathrm{A}$, Q56R. The $A B A T$ gene mutations in the THP-1 cell line were: 984C >A, V328V and 167G>A, Q56R. The mutation sites have no influence on enzyme activity; therefore, these two cell lines were used in the present functional study. The human myeloid leukemia cell line THP-1 was obtained from the Chinese Academy of Sciences (Beijing, China), and the SKM-1 cell line was purchased from Health Science Research Resources Bank (Sennan, Japan). All cells were cultured in RPMI-1640 (HyClone; GE Healthcare Life Sciences, Logan, UT, USA) supplemented with $10 \%$ fetal bovine serum (Gibco; Thermo Fisher Scientific, Inc.) at $37^{\circ} \mathrm{C}$ in an atmosphere containing $5 \% \mathrm{CO}_{2}$.

shRNA sequences that targeted the 3 ' untranslated region of $A B A T$ were designed and cloned into pGMLV-SC5 lentiviral vectors (Genomeditech, Shanghai, China). The oligonucleotide sequences were: Sh1-ABAT, 5'-GCGGGAGGACCTGCTAAA TAA-3'; Sh2-ABAT, 5'-GCTGGAGACGTGCATGATTAA-3'; and Sh3-ABAT, 5'-GGTGACAAATCCATTCGTTTC-3'. SKM-1 and THP-1 cells $\left(1 \times 10^{5}\right)$ were infected with three independent shRNA lentiviruses and a scramble lentivirus (negative control, NC; Genomeditech) at a multiplicity of infection of 80 at $37^{\circ} \mathrm{C}$; cells without lentiviral infection were considered normal control cells. Infection efficiency was evaluated by flow cytometry, according to the percentage of green fluorescent protein (GFP)-positive cells, and RT-qPCR and western blotting after 72 h. Puromycin (cat. no. P8230; Beijing Solarbio Science \& Technology Co., Ltd., Beijing, China) was used to improve the percentage of GFP-positive cells at $72 \mathrm{~h}$.

Drug treatment. For drug treatment, the two cell lines were cultured in complete medium supplemented with 0 , 100, 200 and $400 \mu \mathrm{mol} / 1$ ( \pm )-vigabatrin (Sigma-Aldrich; Merck KGaA, Darmstadt, Germany), which is a specific inhibitor of the GABAT enzyme; the medium was replaced by new complete medium containing $( \pm)$-vigabatrin every $24 \mathrm{~h}$. After 10 days, the cells were harvested for further use (15).

GABAT enzymatic activity assay. GABAT enzymatic activity was detected using the GABAT assay kit (cat. no. E-134; Biomedical Research Service Center, University at Buffalo, Buffalo, NY, USA), according to a previous report (15). Briefly, this assay is based on sequential GABA transamination reaction and glutamate dehydrogenase reaction, which couples the reduction of iodonitrotetrazolium to iodonitrotetrazolium-formazan $\left(\varepsilon=18 \mathrm{mM}^{-1} \mathrm{~cm}^{-1}\right.$ at
$492 \mathrm{~nm})$. Reactions were terminated by adding 3\% acetic acid (cat. no. A6283; Sigma-Aldrich; Merck KGaA) and OD was measured at $492 \mathrm{~nm}$ using a plate reader (Thermo Fisher Scientific, Inc.). A mean of the readings was obtained, and control well readings were subtracted from sample well readings $(\triangle \mathrm{OD})$. GABAT activity was calculated using the following formula: GABAT activity $[\mu \mathrm{mol} /(1 \cdot \mathrm{min})]=(\Delta \mathrm{OD} \mathrm{x}$ $1,000 \times 150 \mu \mathrm{l}) /(60 \mathrm{~min} \times 0.6 \mathrm{~cm} \times 18 \times 5 \mu \mathrm{l})=\Delta \mathrm{OD} \times 46.3$, where $150 \mu \mathrm{l}$ is the total reaction volume, $0.6 \mathrm{~cm}$ is the light path in the 96 -well plate, and $5 \mu \mathrm{l}$ is the volume of the sample in each well.

Cell viability assay. Cell viability was measured using the Cell Counting Kit-8 (CCK-8; Dojindo Molecular Technologies, Inc., Rockville, MD, USA) according to the manufacturer's protocol. Briefly, cells treated with the GABAT inhibitor, cells infected with shRNA lentiviruses, NC cells and normal control cells were seeded in a 96 -well plate at $5 \times 10^{3}$ cells/well. The plates were then incubated for 24,48 and $72 \mathrm{~h}$ at $37^{\circ} \mathrm{C}$ in a humidified incubator containing $5 \% \mathrm{CO}_{2}$. Subsequently, $10 \mu \mathrm{l} \mathrm{CCK}-8$ reagent was added to each well. After $4 \mathrm{~h}$ at $37^{\circ} \mathrm{C}$, absorbance was measured at $450 \mathrm{~nm}$. Three independent experiments were performed.

Measurement of cell apoptosis and cell cycle distribution using flow cytometry. The two cell lines ( $1 \times 10^{5}$ cells) infected with lentiviral vectors or treated with a GABAT inhibitor were harvested and washed with PBS. Cell apoptosis was assessed using Phycoerythrin (PE) Annexin V Apoptosis Detection kit I (cat. no. 559763) and Fluorescein Isothiocyanate (FITC) Annexin V Apoptosis Detection kit I (cat. no. 556547) (both from BD Biosciences, Franklin Lakes, NJ, USA), respectively. Briefly, the cells were harvested and the supernatant was discarded; subsequently, cells were suspended in PBS containing 3\% bovine serum albumin (BSA; cat. no. A8020; Beijing Solarbio Science \& Technology Co., Ltd.) and were adjusted to $1 \times 10^{6}$ cells $/ \mathrm{ml}$. A $100-\mu 1$ aliquot was labeled with $5 \mu \mathrm{l} \mathrm{PE}$ and $5 \mu \mathrm{l}$ 7-aminoactinomycin D (7-AAD) for cells transfected with lentiviruses, or with $5 \mu$ FITC and $5 \mu 1$ propidium iodide (PI) for cells treated with drugs, and cells were incubated at room temperature for $25 \mathrm{~min}$. Flow cytometry was performed immediately after incubation. Data acquisition and analysis were performed using the BD FACSCanto flow cytometer (BD Biosciences) with FCS Express 3.0 software (De Novo Software, Glendale, CA, USA) and FlowJo 7.6 software (FlowJo LLC, Ashland, OR, USA). Normal controls were used to set voltage for flow cytometry. Cells that were Annexin V-positive and 7-amino-actinomycin D (7-AAD)/propidium iodide (PI)-negative were the early apoptotic fraction, whereas cells that were double positive were the late apoptotic fraction.

For cell cycle analysis, the aforementioned leukemia cells $\left(1 \times 10^{5}\right.$ cells) were harvested, washed twice with ice-cold PBS, and fixed with $75 \%$ ethanol at $-20^{\circ} \mathrm{C}$ overnight. Prior to analysis, the fixed cells were washed twice with ice-cold PBS and suspended in $300 \mu \mathrm{l} \mathrm{PI}$ for $15 \mathrm{~min}$ in the dark at $4^{\circ} \mathrm{C}$. The data were acquired using the BD FACSCanto flow cytometer with FCS Express 3.0 software. Data were analyzed using ModFit LT software (version 3.2; Verity Software House, Inc., Topsham, ME, USA). 
Western blot analysis. For western blot analysis, total protein was extracted from the cultured cells using protein lysis buffer (cat. no. 89900; Thermo Fisher Scientific, Inc.) and was quantified using a bicinchoninic acid assay kit (Beyotime Biotechnology, Haimen, China), with BSA (Beijing Solarbio Science \& Technology Co., Ltd.) as a standard. Proteins $(20 \mu \mathrm{g})$ were fractionated by $10 \%$ SDS-PAGE and were transferred onto polyvinylidene fluoride membranes (Bio-Rad Laboratories, Inc.). The membranes were blocked in $5 \%$ non-fat dry milk at room temperature for $2 \mathrm{~h}$ and were immunostained overnight at $4^{\circ} \mathrm{C}$ using antibodies against ABAT (cat. no. ab216465, 1:1,000; Abcam, Cambridge, MA, USA), cyclin D1 (cat. no. 2978S, 1:1,000), cyclin D3 (cat. no. 2936S, 1:1,000), cyclin-dependent kinase (CDK)4 (cat. no. $12790 \mathrm{~S}, 1: 1,000)$, CDK6 (cat. no. $13331 \mathrm{~S}, 1: 1,000)$, p16 ${ }^{\text {INK4a }}$ (cat. no. 80772S, 1:1,000), p21 ${ }^{\text {Waf1/Cip1 }}$ (cat. no. 2947S, 1:1,000), caspase-3 (cat. no. 9665T, 1:1,000), cleaved caspase-3 (cat. no. 9664T, 1:1,000), B-cell lymphoma-2 (Bcl-2)-associated X protein (Bax; cat. no. 2772T, 1:1,000), Bcl-2 (cat. no. 4223T, 1:1,000), GAPDH (cat. no. 2118S, 1:1,000) and $\beta$-actin (cat. no. 8457S, 1:1,000) (Cell Signaling Technology, Danvers, MA, USA). GAPDH and $\beta$-actin antibodies were used as loading controls. After washing with Tris-buffered saline containing $0.1 \%$ Tween, the membranes were incubated with the following secondary antibodies: Anti-rabbit immunoglobulin G (IgG) (cat. no. 7074P2, 1:5,000; Cell Signaling Technology, Inc.) and anti-mouse IgG (cat. no. ab6728, 1:5,000; Abcam) at room temperature for $1 \mathrm{~h}$. The protein bands were visualized using the enhanced chemiluminescence system (Beyotime Institute of Biotechnology). Densitometric analysis of the protein bands was conducted using ImageJ software (Image J $1.48 \mathrm{v}$; National Institutes of Health, Bethesda, MD, USA). The ratio was calculated by comparing the gray value of proteins to GAPDH or $\beta$-actin.

Statistical analysis. All statistical analyses were performed using Stata version 14.0 software (StataCorp LP, College Station, TX, USA); comparisons between two groups were analyzed by independent t-test when data conformed to normal distribution, if not, a non-parametric Kruskal-Wallis test was performed. The $95 \%$ confidence interval (CI) of the expression and methylation levels of $A B A T$ in the 40 control samples was defined as the normal level. Values that were below or above the confidence limit were considered low or high expression/methylation. The independent t-test was used to compare the levels between two groups. One-way analysis of variance followed by Bonferroni post hoc test was used for multiple comparisons. $\chi^{2}$ tests or Fisher's exact tests were used for prognostic analysis.

OS was assessed from the day of diagnosis until death due to any cause, or until the last follow-up date (December 30, 2015). Subjects who succumbed prior to leukemia evolution were censored at the time of death. Kaplan-Meier curves were generated to assess the association of gene expression and methylation with survival, and the log-rank test was performed to analyze the association between different clinical indicators and survival. The Cox regression model was used for multivariate analysis, in order to identify independent prognostic factors affecting OS. $\mathrm{P}<0.05$ was considered to indicate a statistically significant difference.

\section{Results}

mRNA expression levels of ABAT in patients with MDS and $A M L$, and control individuals. The mRNA expression and methylation levels of $A B A T$ were detected in samples obtained from 152 patients with MDS, 29 patients with AML and 40 controls individuals (Fig. 1A-D). The average expression level in the 152 patients with MDS was 0.31 (0.21-0.40), which was significantly lower compared with in the controls $(\mathrm{P}<0.0001$; Fig. 1A and Table I). When the number of bone marrow blast cells was increased, the mRNA expression levels of $A B A T$ were also upregulated (Table I). According to the WHO subtypes of MDS, patients with high-risk subtypes (i.e. RAEB-1 and RAEB-2) exhibited high expression levels compared with low-risk subtypes (i.e., RA, RARS, RCMD, RCMD-RS, 5q-syndrome and MDS-U) ( $\mathrm{P}=0.09$; Fig. 1C and Table I). The low-risk and high-risk subgroups of patients with MDS exhibited lower expression levels than patients with $\mathrm{AML}(\mathrm{P}=0.0001$ and $\mathrm{P}=0.0039$, respectively).

MS-HRM of patients with MDS and AML, and control individuals. The fluorescence intensities of $0,10,25,50,75$ and $100 \%$ methylated DNA standards were detected (data not shown) and the fluorescence intensity of nonmethylated DNA standards was subtracted to determine differential fluorescence intensity. A standard curve was established, with $\mathrm{y}=0.622 \mathrm{x}+0.326, \mathrm{R}^{2}=0.998$ (data not shown). Subsequently, the fluorescence intensities of DNA methylation of 152 patients with MDS, 29 patients with AML and 40 controls were detected, in order to calculate the percentage of $A B A T$ methylation according to the standard curve. The percentage of $A B A T$ gene methylation was higher in subjects with MDS than in controls ( $\mathrm{P}=0.0001)$ (Table I and Fig. 1B). The high-risk subgroup of MDS patients exhibited a higher degree of methylation compared with the low-risk subgroup $(\mathrm{P}<0.0001)$. No difference was determined between patients with AML and low-risk subjects ( $\mathrm{P}=0.417$; Fig. 1D).

Association of the expression and methylation levels of $A B A T$ with the prognosis of patients with MDS. Univariate analysis revealed that age, hemoglobin levels, WHO classification, marrow blast percentage, IPSS karyotype, IPSS cytopenias, IPSS risk group, and the expression and methylation levels of $A B A T$ were significant associated with OS in patients with MDS (Table II). The normal expression levels of $A B A T$ (95\% CI, 0.46-1.25) and the normal methylation percentage of $A B A T$ (95\% CI, 7.98-12.39) were defined in the 40 control samples (Table I). Values below the lower confidence limit were considered the low-expression and low-methylation group; values above the high confidence limit were considered the high-expression and high-methylation group; the other values were considered normal. Therefore, according to this classification, subjects with MDS were categorized into 14 normal-, 131 low- and 7 high-expression patients. In terms of $A B A T$ gene methylation, subjects were categorized into 16 low-, 19 normal- and 117 high-methylation subjects (Table II).

Subjects with normal and high $A B A T$ mRNA expression had a shorter OS compared with those with low expression $(\mathrm{P}=0.015$; Fig. 1E). The median survival time of subjects with 
Table I. ABAT mRNA expression and methylation in patients with MDS and AML, and control individuals.

\begin{tabular}{|c|c|c|c|c|c|}
\hline Variable & $\begin{array}{l}\text { No. of } \\
\text { patients }\end{array}$ & $\begin{array}{c}\text { Relative } A B A T \\
\text { mRNA levels }(95 \% \mathrm{CI})\end{array}$ & P-value & $\begin{array}{c}\text { Degree of } A B A T \text { methylation, } \\
\qquad \%(95 \% \mathrm{CI})\end{array}$ & P-value \\
\hline Group & & & $<0.0001$ & & $<0.0001$ \\
\hline Controls & 40 & $0.86(0.46-1.25)$ & & $10.18(7.98-12.39)$ & \\
\hline MDS patients & 152 & $0.31(0.21-0.40)$ & & $27.23(23.95-30.51)$ & \\
\hline AML patients & 29 & $0.93(0.43-1.43)$ & & $26.99(16.94-37.06)$ & \\
\hline Age (years) & & & 0.542 & & 0.947 \\
\hline$<60$ & 83 & $0.31(0.18-0.45)$ & & $26.98(22.38-31.57)$ & \\
\hline$\geq 60$ & 69 & $0.29(0.15-0.43)$ & & $27.52(22.75-32.30)$ & \\
\hline Sex & & & 0.386 & & 0.788 \\
\hline Male & 92 & $0.34(0.21-0.47)$ & & $26.74(22.76-30.72)$ & \\
\hline Female & 60 & $0.25(0.11-0.39)$ & & $27.97(22.19-33.76)$ & \\
\hline WBCs $\left(\times 10^{9} / 1\right)$ & & & 0.472 & & 0.575 \\
\hline$<4$ & 129 & $0.33(0.21-0.44)$ & & $26.15(22.94-29.37)$ & \\
\hline$\geq 4$ & 23 & $0.19(0.13-0.25)$ & & $33.25(20.68-45.82)$ & \\
\hline Neutrophils $\left(\mathrm{x} 10^{9} / 1\right)$ & & & 0.289 & & 0.286 \\
\hline$<1.5$ & 114 & $0.32(0.20-0.45)$ & & $25.83(22.34-29.32)$ & \\
\hline$\geq 1.5$ & 38 & $0.25(0.15-0.36)$ & & $31.41(23.33-39.49)$ & \\
\hline Hemoglobin (g/dl) & & & 0.336 & & 0.477 \\
\hline$<9$ & 115 & $0.34(0.22-0.46)$ & & $27.04(23.59-30.49)$ & \\
\hline$\geq 9$ & 37 & $0.20(0.12-0.28)$ & & $27.80(19.30-36.31)$ & \\
\hline PLTs (x $\left.10^{9} / 1\right)$ & & & 0.146 & & 0.896 \\
\hline$<100$ & 112 & $0.34(0.21-0.46)$ & & $26.79(23.10-30.48)$ & \\
\hline$\geq 100$ & 40 & $0.21(0.11-0.31)$ & & $28.45(21.22-36.68)$ & \\
\hline WHO classification & & & 0.004 & & $<0.0001$ \\
\hline $\begin{array}{l}\text { RA, RARS, RCMD, } \\
\text { RCMD-RS, } \\
\text { MDS-U, 5q-syndrome }\end{array}$ & 106 & $0.18(0.15-0.21)$ & & $22.62(19.47-25.77)$ & \\
\hline RAEB-1, RAEB-2 & 46 & $0.41(0.31-0.89)$ & & $37.84(30.48-45.20)$ & \\
\hline BM blasts (\%) & & & 0.049 & & $<0.0001$ \\
\hline$<5$ & 106 & $0.18(0.15-0.21)$ & & $22.68(19.54-25.82)$ & \\
\hline $5-9$ & 21 & $0.44(0.16-0.71)$ & & $46.26(33.73-58.79)$ & \\
\hline $10-19$ & 25 & $0.72(0.22-1.21)$ & & $30.86(22.29-39.42)$ & \\
\hline IPSS karyotype ${ }^{a}$ & & & 0.654 & & 0.056 \\
\hline Good & 104 & $0.27(0.17-0.36)$ & & $25.27(21.36-29.16)$ & \\
\hline Intermediate & 29 & $0.38(0.13-0.64)$ & & $28.48(20.87-36.08)$ & \\
\hline Poor & 17 & $0.39(0.07-0.85)$ & & $36.14(24.87-47.41)$ & \\
\hline IPSS cytopenias ${ }^{\mathrm{b}}$ & & & 0.358 & & 0.807 \\
\hline $0 / 1$ & 19 & $0.27(0.07-0.48)$ & & $29.14(16.98-41.30)$ & \\
\hline $2 / 3$ & 133 & $0.31(0.21-0.41)$ & & $26.96(23.56-30.35)$ & \\
\hline IPSS risk group $^{c}$ & & & 0.007 & & 0.004 \\
\hline Low & 13 & $0.20(0.06-0.35)$ & & $23.45(9.06-37.83)$ & \\
\hline INT-1 & 96 & $0.20(0.14-0.26)$ & & $23.72(20.34-27.11)$ & \\
\hline INT-2 & 26 & $0.44(0.11-0.77)$ & & $34.75(25.13-44.37)$ & \\
\hline High & 15 & $0.81(0.15-1.47)$ & & $38.73(24.08-53.39)$ & \\
\hline
\end{tabular}

An independent t-test was used to compare two groups. One-way analysis of variance was used for multiple group comparisons. $A B A T$, 4-aminobutyrate aminotransferase; AML, acute myeloid leukemia; BM, bone marrow; INT, intermediate; IPSS; International Prognostic Scoring System; MDS, myelodysplastic syndrome; MDS-U, unclassified MDS; PLTs, platelets; RA, refractory anemia; RAEB-1; refractory anemia with excess of blasts type 1; RAEB-2, refractory anemia with excess of blasts type 2; RARS, refractory anemia with ring sideroblasts; RCMD, refractory cytopenia with multilineage dysplasia; RCMD-RS, RCMD with ring sideroblasts; WBCs, white blood cells; WHO, World Health Organization. 'IPSS karyotype: Good, normal, 5q-, 20q-, -Y; intermediate, not good or poor; poor, complex aberration or chromosome 7 abnormalities. ${ }^{b}$ IPSS cytopenias: Hemoglobin concentration <9 g/dl, absolute neutrophil count $<1.8 \times 10^{9} / 1$, PLT count $<100 \times 10^{9} / 1$. ' IPSS risk groups: Low, 0; INT-1, 0.5-1.0; INT-2, 1.5-2.0; high, $\geq 2.5$, according to IPSS score. 
A
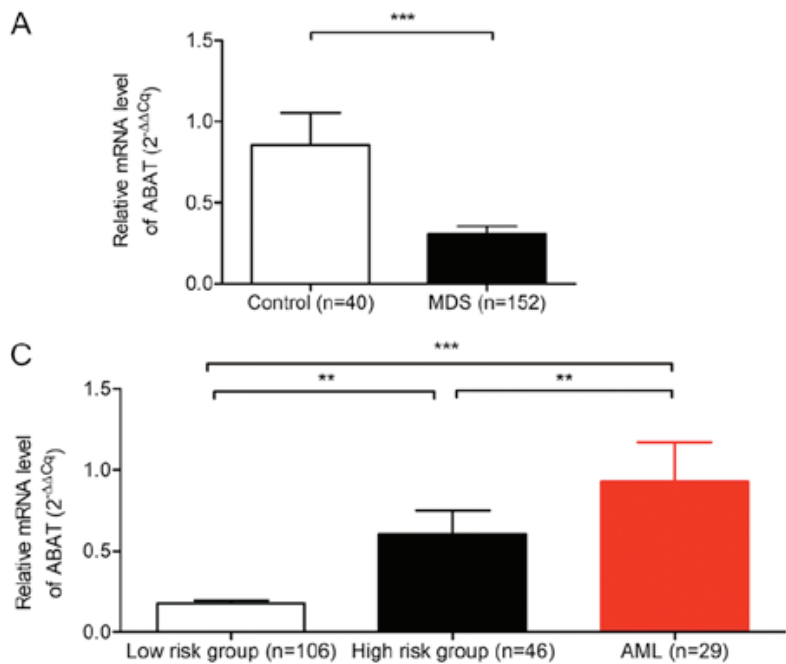

E

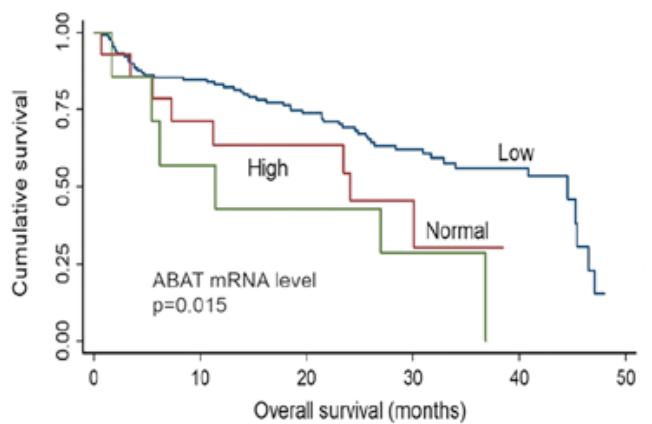

B
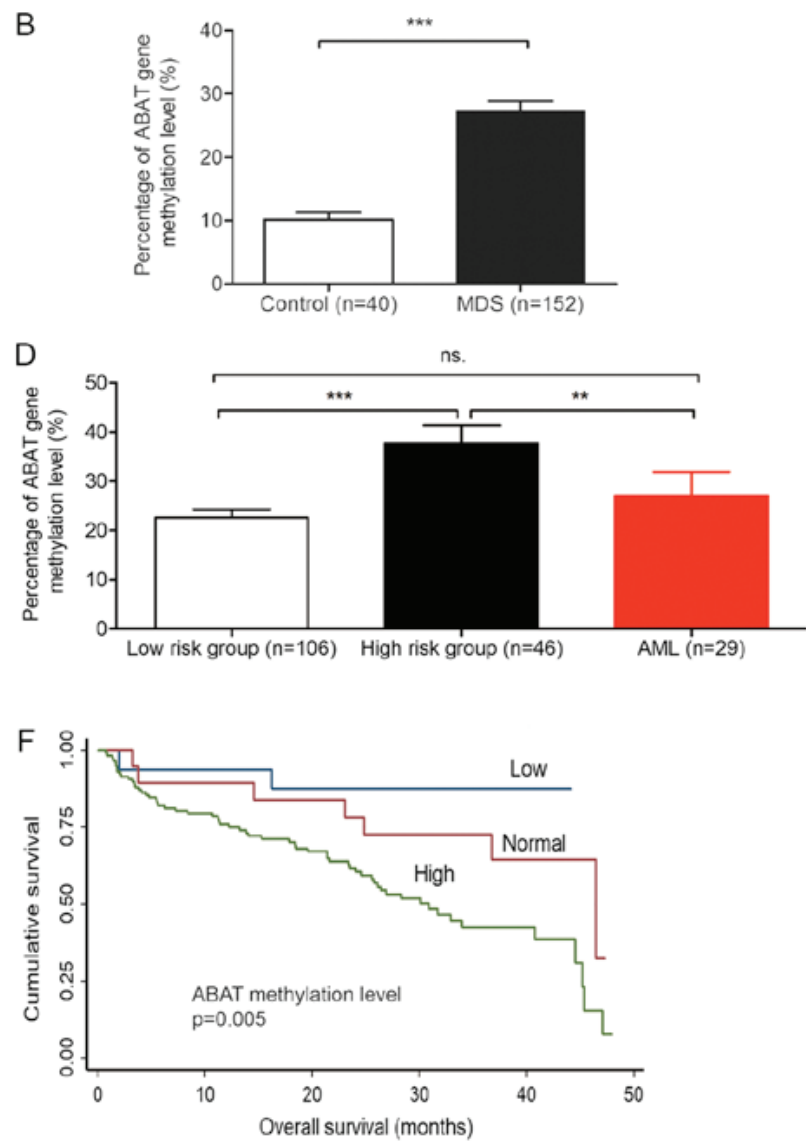

Figure 1. Expression and methylation levels of $A B A T$ in patients with MDS and AML, and control individuals. (A) Reverse transcription-quantitative polymerase chain reaction analysis of relative mRNA expression levels of $A B A T$ in bone marrow samples from patients with MDS and controls. (B) Methylation-sensitive high resolution melting analysis of methylation degree of $A B A T$ in patients with MDS and controls. (C) Relative mRNA expression levels of $A B A T$ were analyzed in low-risk subjects, high-risk subjects and subjects with AML. (D) Methylation levels of $A B A T$ in the three groups. (E) Overall survival curve of patients with MDS with various mRNA expression levels of $A B A T$. (F) Overall survival curve of patients with MDS with various degrees of $A B A T$ methylation. The low-risk MDS group included refractory anemia, refractory anemia with ring sideroblasts, 5q-syndrome, unclassified MDS, RCMD and RCMD with ring sideroblasts subgroups; the high-risk MDS group included RAEB-1 and RAEB-2. ${ }^{* *} \mathrm{P}<0.01$ and ${ }^{* * *} \mathrm{P}<0.001$. ABAT, 4 -aminobutyrate aminotransferase; MDS, myelodysplastic syndrome; RAEB; refractory anemia with excess of blasts; RCMD, refractory cytopenia with multilineage dysplasia.

high expression was 17.88 months. Furthermore, when the degree of methylation increased, OS decreased $(\mathrm{P}=0.005$; Fig. $1 \mathrm{~F})$.

The multivariate Cox regression analysis demonstrated that old age, high blast count and high methylation had a strong impact on the OS of patients with MDS (hazard ratios=2.51, 2.26 and 1.93, respectively); therefore, these were considered independent risk factors for the survival of patients with MDS (Table III). Although ABAT mRNA expression had prognostic value in the univariate analysis, the multivariate analysis revealed that the expression of $A B A T$ was not an independent factor affecting $\mathrm{OS}(\mathrm{P}=0.856)$.

Effects of ABAT shRNA on SKM-1 and THP-1 cells. The mRNA and protein expression levels of $A B A T$ were detected in the various cell groups (Fig. 2). There was no difference in $A B A T$ expression between SKM-1 and THP-1 cell lines (data not shown). HL-60 is also a human leukemia cell line; however, due to its low expression of $A B A T$ (data not shown), SKM-1 and THP-1 cells were used in this study. Three lentiviral vectors were constructed containing three different shRNA sequences (i.e. Sh1-ABAT, Sh2-ABAT and Sh3-ABAT), in order to explore the biological function of $A B A T$ in leukemia cell lines. Following infection with the three vectors, the mRNA expression levels of $A B A T$ were decreased by 90 , 70 and 50\% in SKM-1 cells compared with the NC group, respectively (Fig. 2A). In THP-1 cells, following infection with the three vectors, the mRNA expression levels of $A B A T$ were decreased by 80,60 and $40 \%$, respectively (Fig. 2B). There was no difference between the normal control and negative control groups with regards to $A B A T$ mRNA expression. The protein expression levels of $A B A T$ were decreased by $\sim 90,80$ and $50 \%$ (Fig. $2 \mathrm{C}$ and E) in the Sh1-ABAT, Sh2-ABAT and Sh3-ABAT SKM-1 cells, and by 60,55 and $30 \%$ in the THP-1 cells (Fig. 2D and F) compared with the NC group, respectively. Since the Sh3-ABAT lentivirus exerted minor effects on the mRNA and protein expression levels of $A B A T$, Sh1- $A B A T$ and Sh2-ABAT lentiviruses were used for further functional analysis.

Relative activity of GABAT in cells infected with shRNA lentiviruses and treated with a GABAT inhibitor. Relative GABAT activity was detected following infection of SKM-1 and THP-1 cells with shRNA lentiviruses. Relative GABAT activity was decreased by 65 and $40 \%$ in the Sh1-ABAT and Sh2-ABAT groups compared with in the NC group in SKM-1 cells (Fig. 2G), and by 35 and $40 \%$ in THP-1 cells (Fig. 2H), 
A

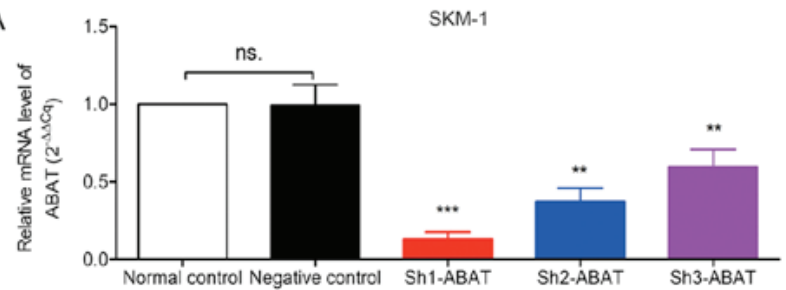

$B$

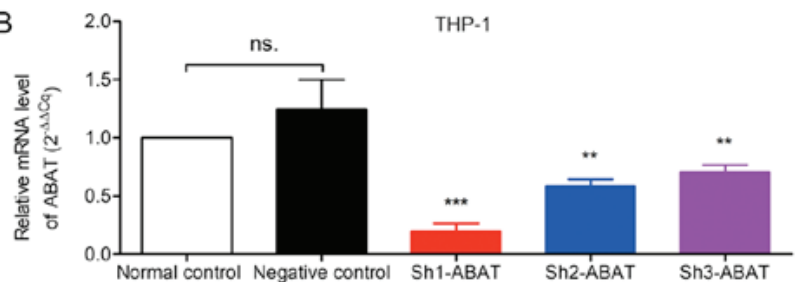

E

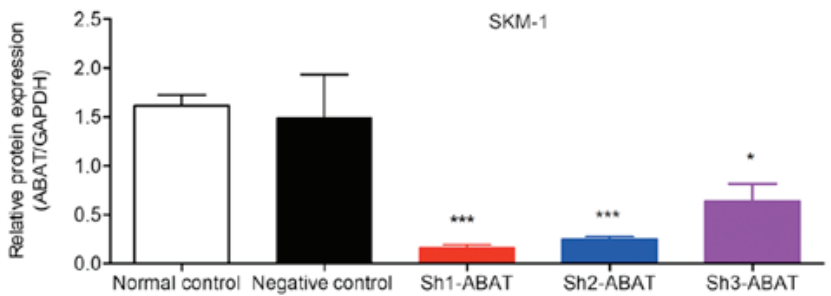

$\mathrm{F}$

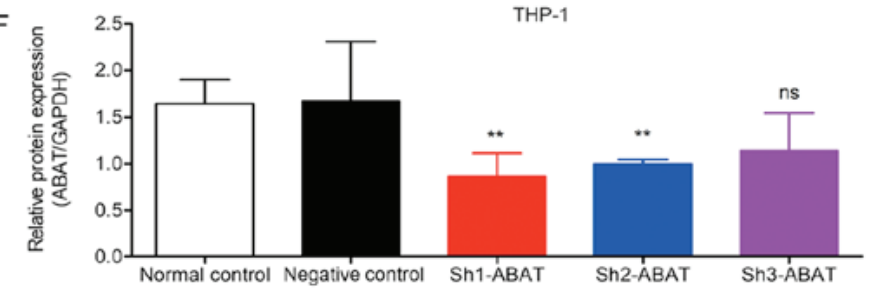

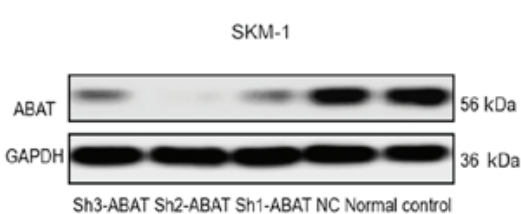

G

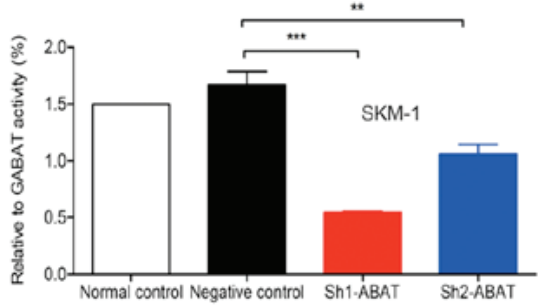

D

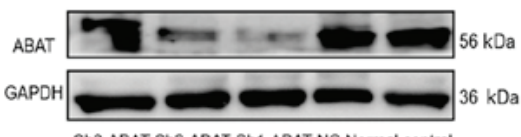

Sh3-ABAT Sh2-ABAT Sh1-ABAT NC Normal control

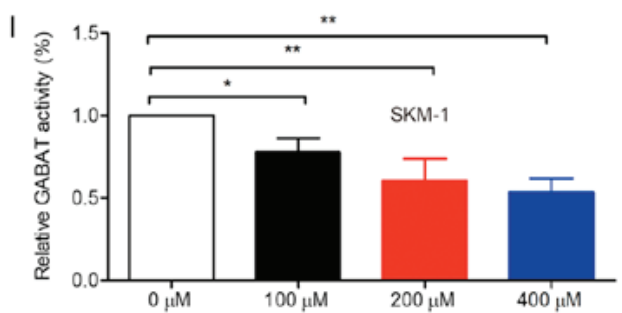

$\mathrm{H}$
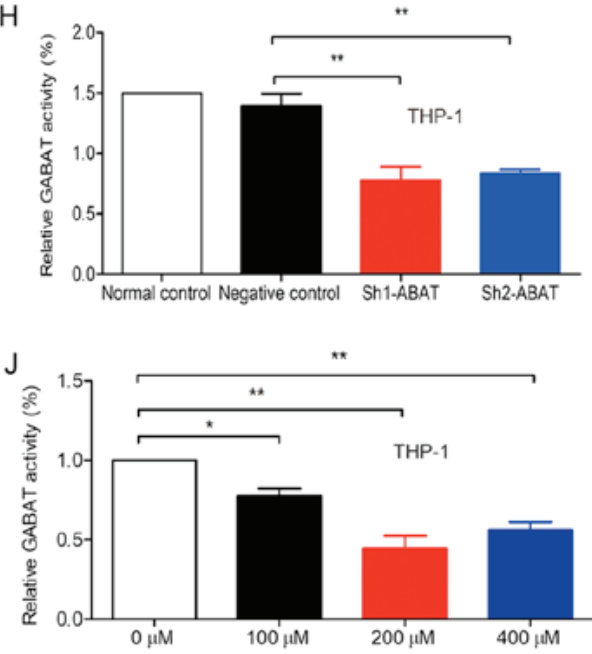

Figure 2. Expression levels of $A B A T$ and relative enzyme activity of GABAT in SKM-1 and THP-1 cells. Relative mRNA expression levels of $A B A T$ in (A) SKM-1 and (B) THP-1 cells $72 \mathrm{~h}$ post-infection, as determined by reverse transcription-quantitative polymerase chain reaction. Normal control cells were not infected with a lentiviral vector. Western blot analysis of (C) SKM-1 and (D) THP-1 cells in the normal control, NC and shRNA lentivirus groups. Gray value analysis of $A B A T$ protein expression in (E) SKM-1 and (F) THP-1 cells infected with NC and shRNA lentiviruses. Relative enzyme activity of GABAT in (G) SKM-1 and (H) THP-1 cells with $A B A T$ silencing. Relative activity of GABAT in (I) SKM-1 and (J) THP-1 cells treated with various concentrations of GABAT inhibitor. Data are presented as the means \pm standard deviation. ${ }^{*} \mathrm{P}<0.05,{ }^{* * *} \mathrm{P}<0.01$ and ${ }^{* * *} \mathrm{P}<0.001$ vs. the normal control or $0 \mu \mathrm{M}$ group. $A B A T, 4$-aminobutyrate aminotransferase; GABAT, $\gamma$-aminobutyrate aminotransferase; NC, negative control; ns, not significant; sh/shRNA, short hairpin RNA.

respectively. ( \pm )-vigabatrin is a specific inhibitor of GABAT; therefore, relative activity of GABAT was also detected in cells following vigabatrin treatment. When the dose of vigabatrin was increased, GABAT activity was decreased to $70 \%$ in the $100 \mu \mathrm{M}$ group, $60 \%$ in the $200 \mu \mathrm{M}$ group and $55 \%$ in the $400 \mu \mathrm{M}$ group compared with in the control group in SKM-1 cells (Fig. 2I). In THP-1 cells, relative GABAT activity was decreased to 70,40 and 45\% in the 100, 200 and $400 \mu \mathrm{M}$ groups, respectively, compared with in the control group (Fig. 2J).

ABAT gene silencing and GABAT inhibition inhibits leukemia cell viability. SKM-1 and THP-1 cells were infected with shRNA lentiviruses and the effects of $A B A T$ knockdown on viability were evaluated. Cells that were not infected with lentivirus or treated with the GABAT inhibitor were considered normal controls; all results were compared to the normal control group. The results revealed that when the expression levels of $A B A T$ were decreased, cell viability was significantly inhibited (Fig. 3A and B). Furthermore, treatment with the GABAT inhibitor also inhibited the viability of SKM-1 and THP-1 cells (Fig. 3C and D). Taken together, these data indicated important roles for $A B A T$ and GABAT in the pathogenesis of MDS.

Apoptosis of cells with ABAT gene silencing and following treatment with a GABAT inhibitor. Cell apoptosis is generally used as an indicator of alterations in biological behavior. Annexin V-PE/7-AAD and Annexin V/PI staining, followed by flow cytometry, were used to analyze apoptosis of cells infected with lentiviruses and treated with vigabatrin, in order to determine whether cell apoptosis was affected by $A B A T$ gene silencing and GABAT inhibition. As shown in Fig. 4, the percentage of cell apoptosis increased following $A B A T$ gene knockdown using Sh1- $A B A T$ and Sh2-ABAT lentiviruses. The fraction of apoptotic cells was $29.07 \pm 0.21$ and $11.40 \pm 0.57 \%$ in Sh1-ABAT- and Sh2-ABAT-infected SKM-1 cells, and $3.04 \pm 0.27 \%$ in the negative control group (Fig. 4A and C). The 
A

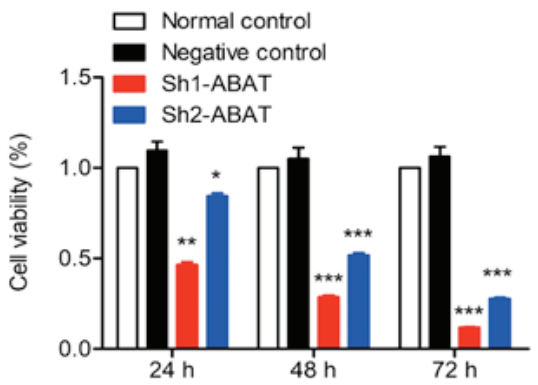

B

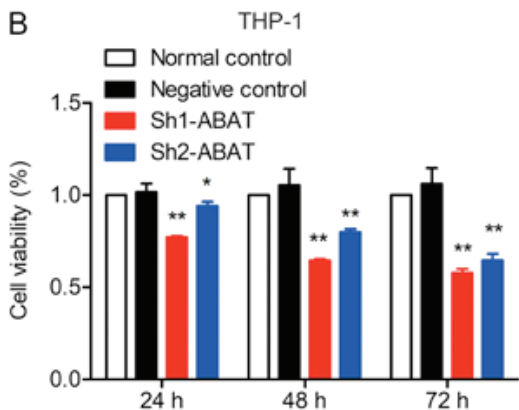

C

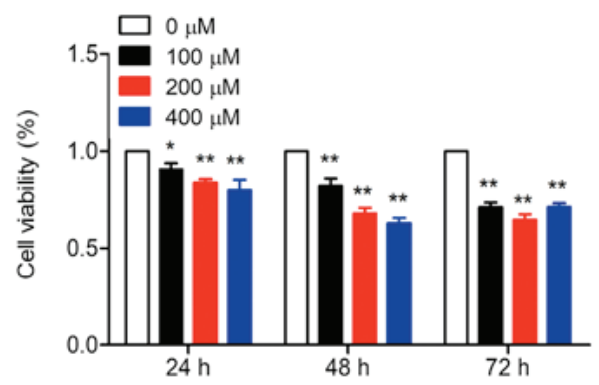

D

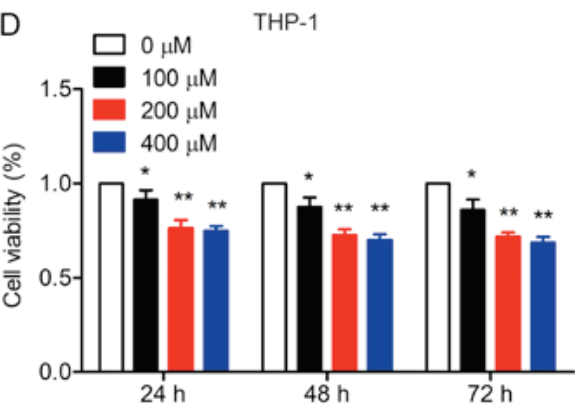

Figure 3. Viability of SKM-1 and THP-1 cells with ABAT gene silencing and GABAT inhibitor treatment. Viability of (A) SKM-1 and (B) THP-1 cells with $A B A T$ gene silencing following puromycin selection at 24, 48 and $72 \mathrm{~h}$. Viability of (C) SKM-1 and (D) THP-1 cells treated with various concentrations $(0,100$, 200 and $400 \mu \mathrm{M}$ ) of the $\mathrm{GABAT}$ inhibitor. ${ }^{*} \mathrm{P}<0.05,{ }^{* *} \mathrm{P}<0.01$ and ${ }^{* * *} \mathrm{P}<0.001$ vs. the normal control or $0 \mu \mathrm{M}$ group. ABAT, 4-aminobutyrate aminotransferase; GABAT, $\gamma$-aminobutyrate aminotransferase; sh, short hairpin RNA.

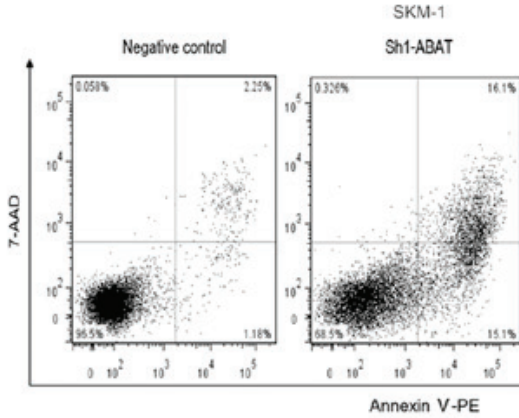

C

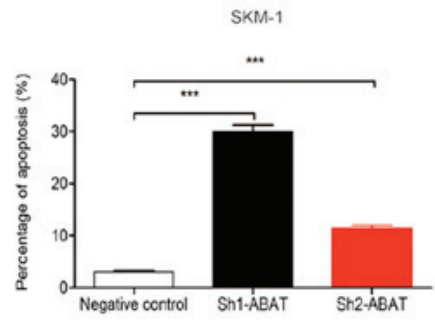

$\mathrm{F}$

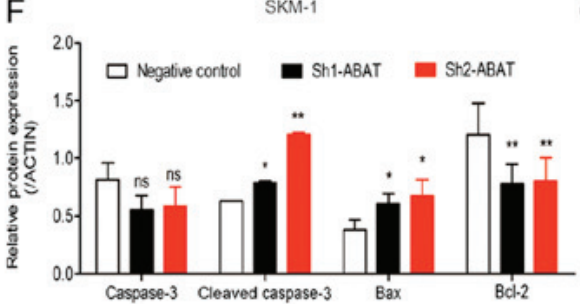

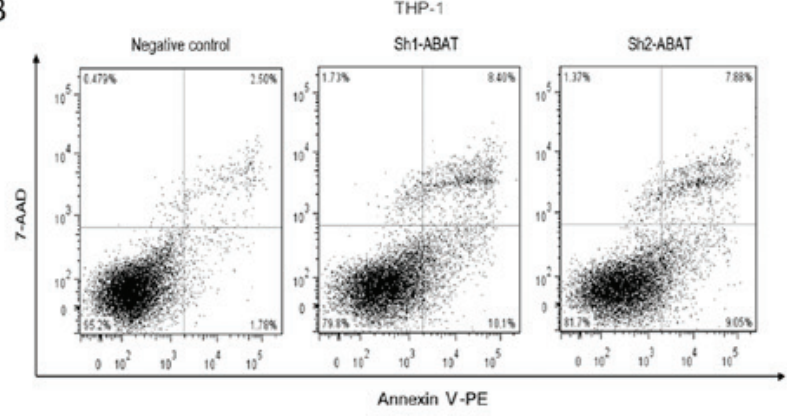

D THP.1

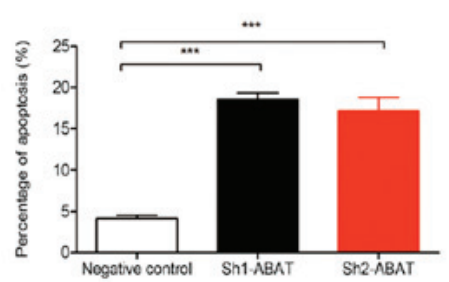

E

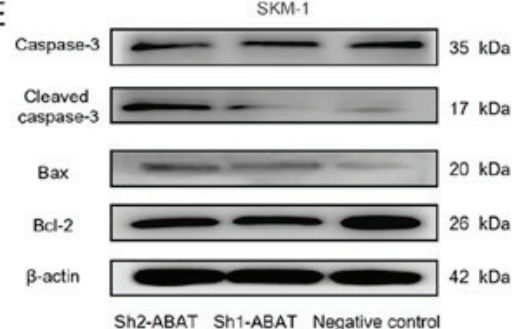

G

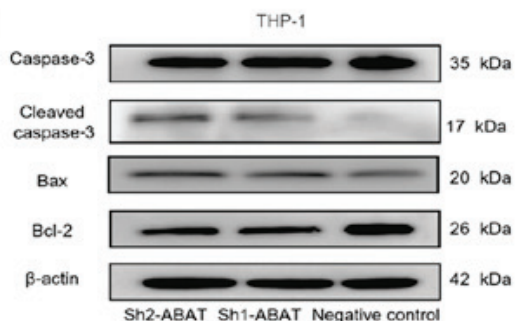

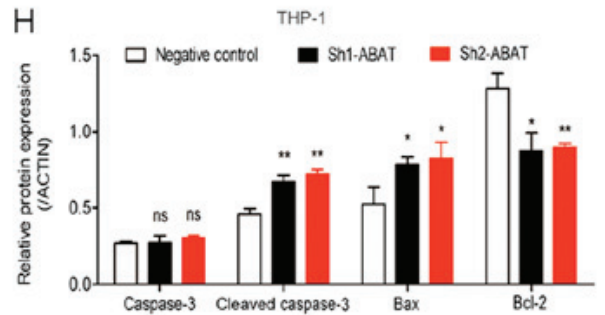

Figure 4. Apoptosis analysis of SKM-1 and THP-1 cells following ABAT gene silencing using flow cytometry and western blotting. Apoptosis of (A) SKM-1 and (B) THP-1 cells with ABAT gene silencing, as determined by Annexin V-PE/7-AAD staining at $72 \mathrm{~h}$. (C) Percentage of apoptotic (C) SKM-1 and (D) THP-1 cells following infection with negative control and shRNA lentiviruses. Western blot analysis of apoptosis-associated proteins in (E and F) SKM-1 and (G and H) THP-1 cells with $A B A T$ gene silencing at $72 \mathrm{~h}$, including caspase-3, cleaved caspase-3, Bax and Bcl-2. (F and H) Gray value analysis of apoptotic proteins was conducted. Data are presented as the means \pm standard deviation. ${ }^{*} \mathrm{P}<0.05,{ }^{* *} \mathrm{P}<0.01$ and ${ }^{* * * *} \mathrm{P}<0.001$ vs. negative control or as indicated. 7-AAD, 7-amino-actinomycin $\mathrm{D} ; A B A T$, 4-aminobutyrate aminotransferase; Bax, Bcl-2-associated X protein; Bcl-2, B-cell lymphoma-2; PE, phycoerythrin; sh/shRNA, short hairpin RNA. 
Table II. Univariate analysis of prognostic factors for patients with MDS.

\begin{tabular}{|c|c|c|c|}
\hline Variable & $\begin{array}{l}\text { No. of } \\
\text { patients }\end{array}$ & $\begin{array}{l}\text { Cases of } \\
\text { mortality }\end{array}$ & P-value \\
\hline Age (years) & & & 0.004 \\
\hline$<60$ & 83 & 31 & \\
\hline$\geq 60$ & 69 & 38 & \\
\hline Sex & & & 0.996 \\
\hline Male & 92 & 41 & \\
\hline Female & 60 & 28 & \\
\hline WBCs $\left(\times 10^{9} / 1\right)$ & & & 0.804 \\
\hline$<4$ & 129 & 59 & \\
\hline$\geq 4$ & 23 & 10 & \\
\hline Neutrophils (x 109/1) & & & 0.310 \\
\hline$<1.5$ & 114 & 56 & \\
\hline$\geq 1.5$ & 38 & 13 & \\
\hline Hemoglobin (g/dl) & & & 0.005 \\
\hline$<9$ & 115 & 59 & \\
\hline$\geq 9$ & 37 & 10 & \\
\hline PLTs $\left(\times 10^{9} / 1\right)$ & & & 0.070 \\
\hline$<100$ & 112 & 56 & \\
\hline$\geq 100$ & 40 & 13 & \\
\hline WHO classification & & & $<0.001$ \\
\hline $\begin{array}{l}\text { RA, RARS, RCMD, RCMD-RS, } \\
\text { 5q-syndrome, MDS-U }\end{array}$ & 106 & 33 & \\
\hline RAEB-1, RAEB-2 & 46 & 36 & \\
\hline BM blasts $(\%)$ & & & $<0.001$ \\
\hline$<5$ & 106 & 32 & \\
\hline $5-9$ & 21 & 17 & \\
\hline $10-19$ & 25 & 20 & \\
\hline IPSS karyotype ${ }^{a}$ & & & 0.007 \\
\hline Good & 104 & 41 & \\
\hline Intermediate & 29 & 15 & \\
\hline Poor & 17 & 12 & \\
\hline IPSS cytopenias $^{\mathrm{b}}$ & & & 0.045 \\
\hline $0 / 1$ & 19 & 4 & \\
\hline $2 / 3$ & 133 & 65 & \\
\hline IPSS risk groups ${ }^{\mathrm{c}}$ & & & $<0.001$ \\
\hline Low & 13 & 2 & \\
\hline INT-1 & 96 & 33 & \\
\hline INT-2 & 26 & 21 & \\
\hline High & 15 & 12 & \\
\hline$A B A T$ mRNA expression & & & 0.015 \\
\hline Low $(<0.46)$ & 131 & 55 & \\
\hline Normal (0.46-1.25) & 14 & 8 & \\
\hline $\operatorname{High}(>1.25)$ & 7 & 6 & \\
\hline$A B A T$ methylation degree (\%) & & & 0.005 \\
\hline Low $(<7.98)$ & 16 & 2 & \\
\hline Normal (7.98-12.39) & 19 & 7 & \\
\hline High $(>12.39)$ & 117 & 60 & \\
\hline
\end{tabular}

For evaluation of prognostic factors, $\chi^{2}$ tests or Fisher's exact tests were used. $A B A T, 4$-aminobutyrate aminotransferase; $\mathrm{BM}$, bone marrow; $\mathrm{CI}$, confidence interval; INT, intermediate; IPSS; International Prognostic Scoring System; MDS, myelodysplastic syndrome; MDS-U, unclassified MDS; PLTs, platelets; RA, refractory anemia; RAEB-1; refractory anemia with excess of blasts type 1 ; RAEB-2, refractory anemia with excess of blasts type 2; RARS, refractory anemia with ring sideroblasts; RCMD, refractory cytopenia with multilineage dysplasia; RCMD-RS, RCMD with ring sideroblasts; WBCs, white blood cells; WHO, World Health Organization. ' IPSS karyotype: Good, normal, 5q-, 20q-, -Y; intermediate, not good or poor; poor, complex aberration or chromosome 7 abnormalities. ' IPSS cytopenias: Hemoglobin concentration $<9 \mathrm{~g} / \mathrm{dl}$, absolute neutrophil count $<1.8 \times 10^{9} / 1$, PLT count $<100 \times 10^{9} / 1$. ${ }^{c}$ IPSS risk groups: Low, 0 ; INT-1, 0.5-1.0; INT-2, 1.5-2.0; high, $\geq 2.5$, according to IPSS score.
Table III. Multivariate analysis of prognostic factors in patients with myelodysplastic syndrome.

\begin{tabular}{lcc}
\hline Variable & HR $(95 \% \mathrm{CI})$ & P-value \\
\hline Age $(\geq 60$ years $)$ & $2.51(1.48-4.25)$ & 0.001 \\
Hemoglobin $(<9 \mathrm{~g} / \mathrm{dl})$ & $0.79(0.36-1.74)$ & 0.573 \\
BM blasts $(\geq 5 \%)$ & $2.26(1.66-3.09)$ & $<0.0001$ \\
IPSS karyotype (poor) & $1.27(0.91-1.78)$ & 0.145 \\
IPSS cytopenias (2/3) & $1.38(0.89-2.16)$ & 0.148 \\
ABAT mRNA expression (high) & $1.04(0.68-1.57)$ & 0.856 \\
Degree of $A B A T$ methylation (high) & $1.93(1.09-3.40)$ & 0.022 \\
\hline
\end{tabular}

$A B A T, 4$-aminobutyrate aminotransferase; BM, bone marrow; CI, confidence interval; HR, hazard ratio; IPSS, International Prognostic Scoring System.

percentage of apoptotic cells was $18.53 \pm 0.81(\mathrm{P}<0.001)$ and $17.18 \pm 1.6 \%(\mathrm{P}<0.001)$ in Sh1-ABAT- and Sh2-ABAT-infected THP-1 cells compared with in the negative control group (Fig. 4B and D). The expression levels of apoptosis-associated proteins, including cleaved caspase- 3 and Bax were increased, whereas the expression levels of the anti-apoptotic protein Bcl-2 were decreased in SKM-1 (Fig. 4E and F) and THP-1 cells (Fig. 4G and $\mathrm{H}$ ) in response to ABAT knockdown.

Cell apoptosis was also detected following drug treatment. Treatment with a GABAT inhibitor had a minor impact on cell apoptosis. In SKM-1 cells, the percentage of apoptotic cells was $5.35 \pm 0.65,5.50 \pm 0.46,6.67 \pm 0.19$ and $6.84 \pm 1.15 \%$ following treatment with $0,100,200$ and $400 \mu \mathrm{M}$ vigabatrin, respectively (data not shown). In THP-1 cells, the percentage of apoptotic cells was $4.97 \pm 0.82,5.07 \pm 0.13,5.80 \pm 0.94$ and $5.49 \pm 1.2 \%$ following treatment with $0,100,200$ and $400 \mu \mathrm{M}$ vigabatrin, respectively; no statistically significant difference was detected between the groups (data not shown). In addition, the expression levels of apoptosis-associated proteins exhibited no difference between the control and drug-treated groups (data no shown).

Effects of ABAT gene silencing and GABAT inhibition on cell cycle distribution. Cell cycle distribution was detected in the two cell lines, in order to identify whether the inhibitory effects of $A B A T$ gene silencing and GABAT inhibition on growth could be explained by alterations in the cell cycle. In SKM-1 cells, following infection with Sh1-ABAT and Sh2-ABAT, the percentage of cells in $\mathrm{G}_{1}$ phase was increased to $53.09 \pm 4.69(\mathrm{P}<0.01)$ and $52.85 \pm 2.54 \%(\mathrm{P}<0.01)$ compared with in the negative control group, and the percentage of cells in $\mathrm{S}$ phase was decreased to $34.28 \pm 0.29$ and $34.89 \pm 0.22 \%$, respectively (Fig. 5A). The same trend was observed in the THP-1 cells (Fig. 5B). There was no difference between the negative control and normal control groups. In these two cell lines, cell cycle-associated proteins were also detected. The protein expression levels of CDK6, CDK4, cyclin D1 and cyclin D3 were significantly downregulated, whereas the expression levels of the periodic inhibitory proteins, $\mathrm{p} 16^{\mathrm{INK} 4 \mathrm{a}}$ and $\mathrm{p} 21^{\text {Waf1/Cip1 }}$, were upregulated in SKM-1 cells in response to $A B A T$ knockdown (Fig. 5C and D). Conversely, in THP-1 cells, the expression of $\mathrm{p} 21^{\text {Waf1/Cipl }}$ was decreased (Fig. 5E and F).

Cell cycle distribution was also measured following drug treatment. When SKM-1 and THP-1 cells were treated with 

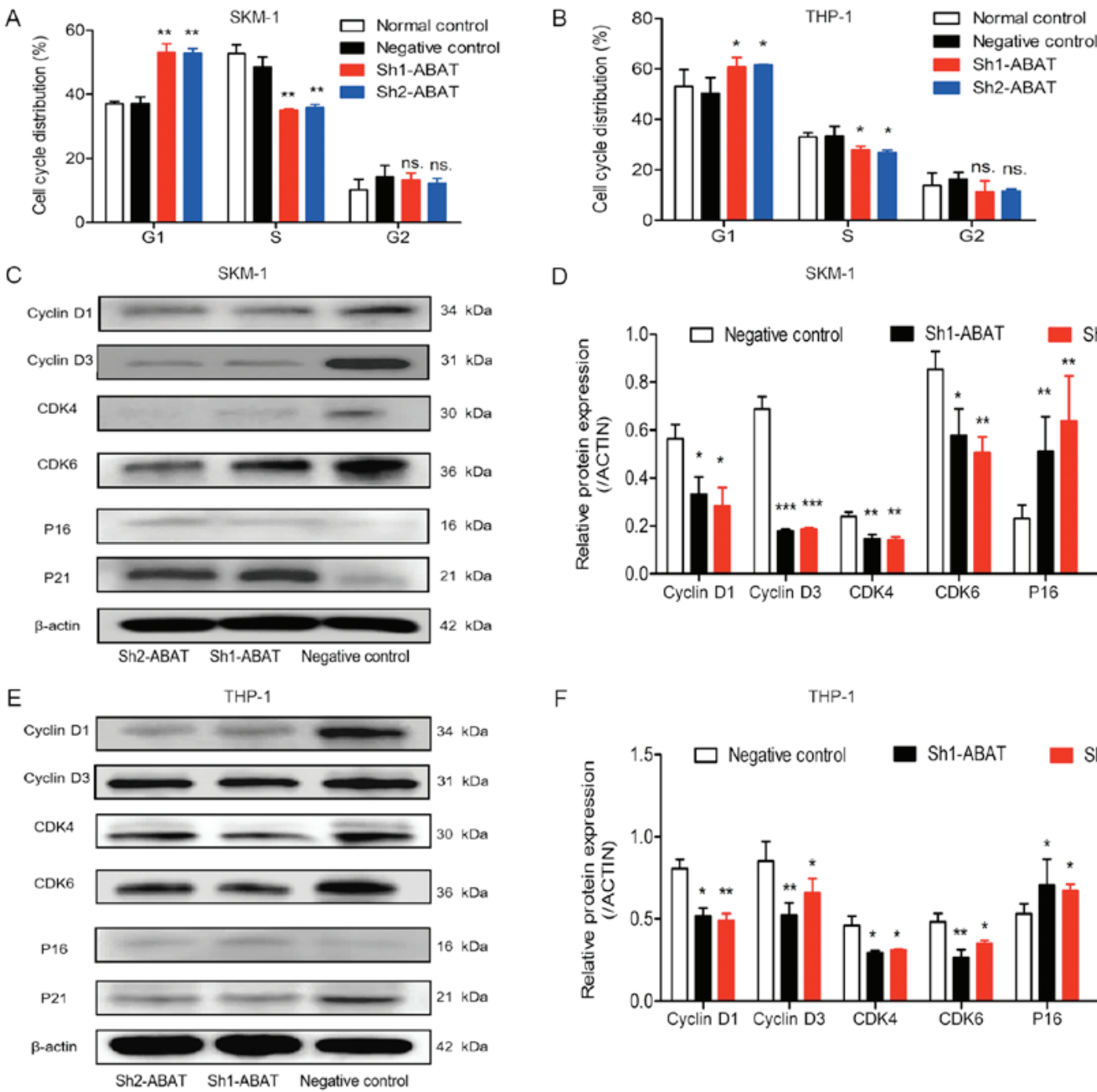

D SKM-1

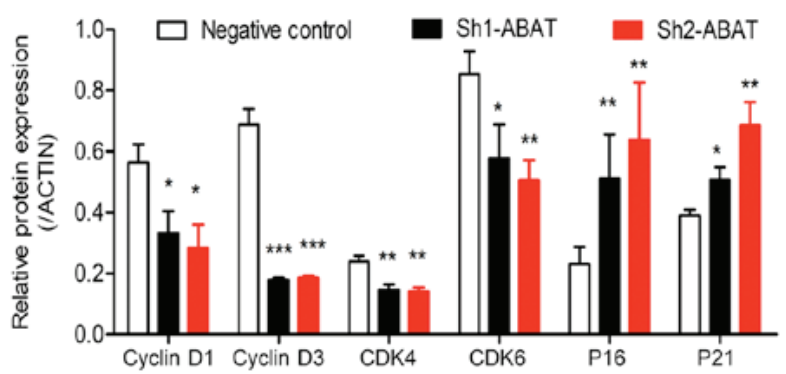

$\mathrm{F}$

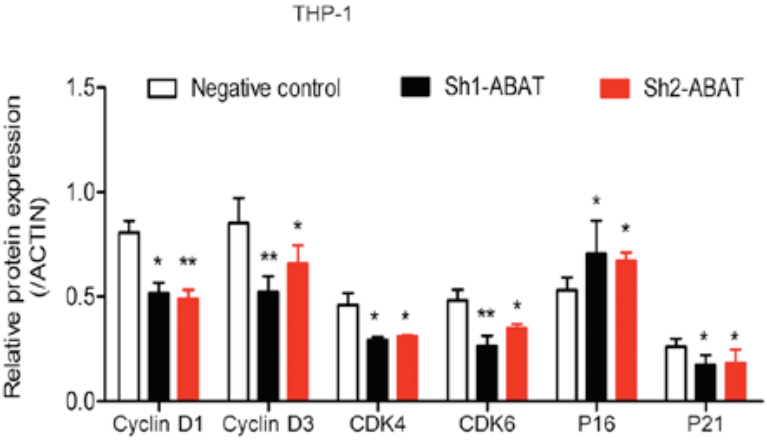

Figure 5. Cell cycle distribution and associated protein expression in SKM-1 and THP-1 cells following ABAT gene silencing. Cell cycle distribution of (A) SKM-1 and (B) THP-1 cells in the normal control, negative control and sh-ABAT groups. Expression levels of cell cycle proteins in (C and D) SKM-1 cells and (E and F) THP-1 cells with ABAT gene silencing, including cyclin D1, cyclin D3, CDK4, CDK6, p16 and p21. (D and F) Gray value analysis of cell cycle-associated proteins was conducted. ${ }^{*} \mathrm{P}<0.05,{ }^{* *} \mathrm{P}<0.01$ and ${ }^{* * *} \mathrm{P}<0.001$ vs. the negative control group or normal control group. ABAT, 4-aminobutyrate aminotransferase; CDK, cyclin-dependent kinase; ns, not significant; sh, short hairpin RNA.

100, 200 and $400 \mu \mathrm{M}$ vigabatrin for 10 days, the percentage of cells in $\mathrm{G}_{0} / \mathrm{G}_{1}$ phase was slightly increased (Fig. $6 \mathrm{~A}$ and $\mathrm{B}$ ). Furthermore, in SKM-1 cells, the percentage of cells in S phase was decreased from $50.28 \pm 5.82 \%$ to $43.51 \pm 1.12,43.83 \pm 2.49$ and $44.32 \pm 0.87 \%$ in response to 100,200 and $400 \mu \mathrm{M}$ vigabatrin (Fig. 6A). In THP-1 cells, the percentage of cells in $\mathrm{S}$ phase was decreased from $25.44 \pm 1.65 \%$ to $21.90 \pm 0.61,22.09 \pm 1.44$ and $21.61 \pm 0.30 \%$ in response to 100,200 and $400 \mu \mathrm{M}$ vigabatrin (Fig. 6B). The expression levels of cell cycle-associated proteins were also detected by western blotting. A similar trend was observed in cells treated with the GABAT inhibitor as in cells with $A B A T$ gene knockdown (Fig. 6C-F).

\section{Discussion}

Alterations in DNA methylation have been implicated in the pathogenesis of MDS and AML, and methylation serves as an indicator for disease progression and treatment efficacy (5). Several genes have been reported to be highly methylated in patients with MDS, including fragile histidine triad, inhibitor of DNA binding 4, HLH protein, suppressor of cytokine signaling 1 and glutathione peroxidase 3 . As the disease progresses, these genes exhibit a higher methylation degree in high-risk groups compared with in low-risk groups (16-20). In the present study, high-risk patients (RAEB-1 and RAEB-2) with MDS exhibited a higher degree of $A B A T$ gene methylation compared with low-risk subjects. Furthermore, patients with high methylation of $A B A T$ had a poor prognosis, which was in concordance with previous reports on other genes in patients with MDS $(16,18,21,22)$. Notably, when the number of bone marrow blasts and the IPSS risk group increased, the degree of $A B A T$ methylation also increased. Therefore, it may be concluded that increased methylation of $A B A T$ could indicate progression in patients with MDS.

Chromosomal abnormalities and gene mutations are considered progression-associated drivers in patients with MDS (23). Several gene mutations, including in isocitrate dehydrogenase (NADP $(+))$ 1, cytosolic $(I D H 1)$, isocitrate dehydrogenase (NADP $(+)) 2$, mitochondrial (IDH2), tet methylcytosine dioxygenase 2, ASXL transcriptional regulator 1 


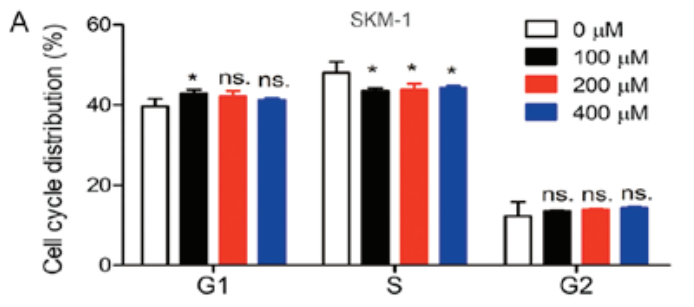

C

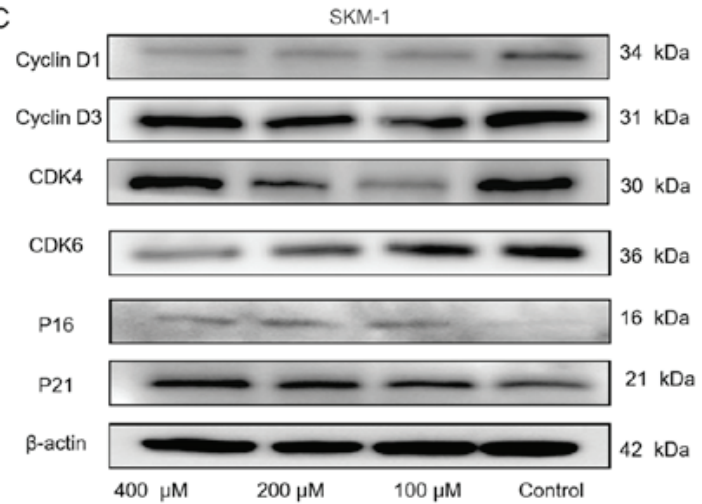

E

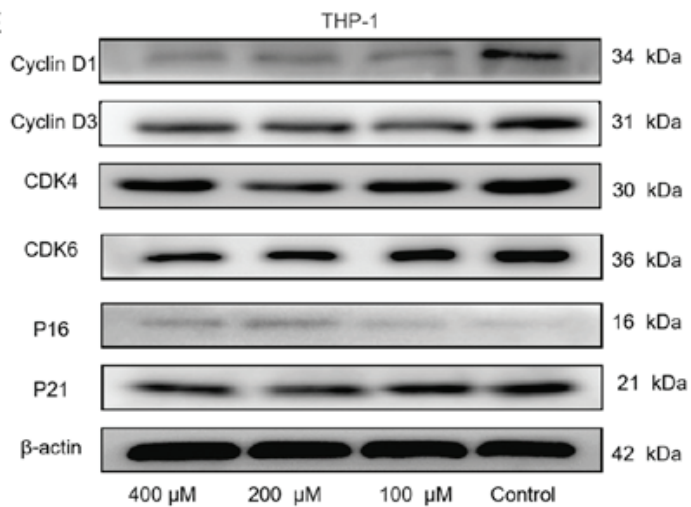

B

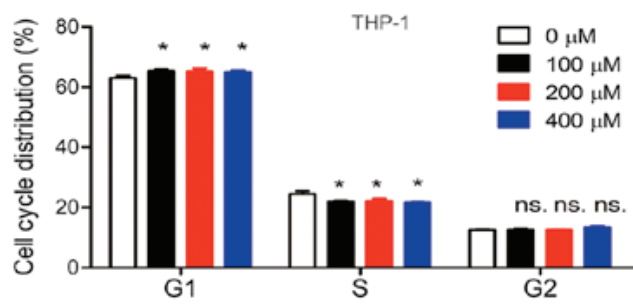

D

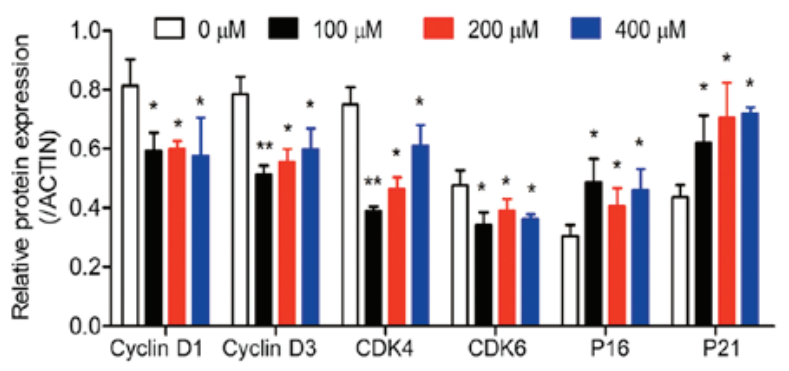

$\mathrm{F}$

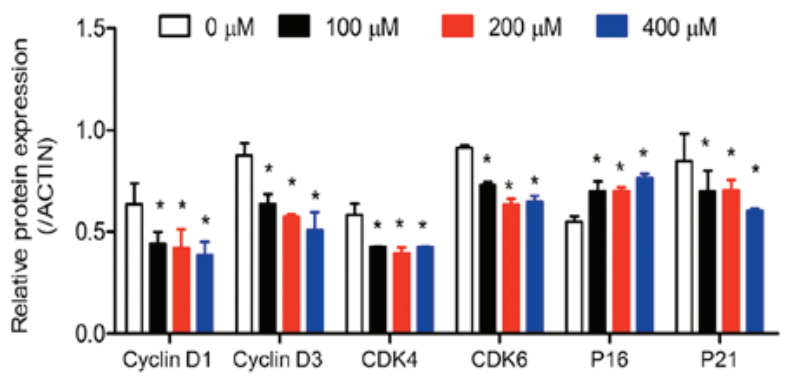

Figure 6. Cell cycle distribution and associated protein expression in SKM-1 and THP-1 cells treated with various concentrations of a $\gamma$-aminobutyrate aminotransferase inhibitor $(0,100,200$ and $400 \mu \mathrm{M})$. Cell cycle distribution in (A) SKM-1 and (B) THP-1 cells following treatment with various drug concentrations. Expression levels of cell cycle-associated proteins in (C and D) SKM-1 and (E and F) THP-1 cells following treatment with various drug concentrations. (D and F) Gray value analysis of cell cycle-associated proteins was conducted. Data are presented as the means \pm standard deviation. ${ }^{*} \mathrm{P}<0.05$ and ${ }^{* *} \mathrm{P}<0.01$ vs. $0 \mu \mathrm{M}$. ABAT, 4-aminobutyrate aminotransferase; CDK, cyclin-dependent kinase; ns, not significant.

and enhancer of zeste 2 polycomb repressive complex 2 subunit, have been revealed to induce epigenetic alterations in hematological malignancies (24). GABAT can catalyze the conversion of GABA into succinic semialdehyde (SSA). SSA is then reduced by SSA dehydrogenase to form succinic acid, which enters the tricarboxylic acid (TCA) cycle $(25,26)$. Mutations in $I D H I$ and $I D H 2$ genes, which serve an important role in the TCA cycle, have been reported to participate in the pathogenesis and progression of MDS (27); therefore, it was hypothesized that mutations in the $A B A T$ gene may be involved in the pathogenesis of MDS, due to its relation to the TCA cycle. However, the frequency of $A B A T$ mutations is very low; the mutation sites include $631 \mathrm{C}>\mathrm{T}, 275 \mathrm{G}>\mathrm{A}$, $1433 \mathrm{~T}>\mathrm{C}, 659 \mathrm{G}>\mathrm{A}, 454 \mathrm{C}>\mathrm{T}$ and $888 \mathrm{G}>\mathrm{T}(8,15,28) . A B A T$ mutations can lead to inactivation of $A B A T$ and elevated GABA concentrations. Patients with these mutations display symptoms, including severe psychomotor retardation, hypotonia, hyperreflexia, seizures, high-pitched cry, growth acceleration and early mortality (8). However, in the present study, the patients with MDS exhibited no such symptoms; therefore, it was hypothesized that these patients did not have
$A B A T$ mutations. Single-nucleotide polymorphisms (SNPs) of $A B A T$ have been reported to be closely associated with numerous diseases, including autism, gastroesophageal reflux disease and affective disorder (29-31). Therefore, the existence of SNPs and their correlation with MDS may be worth exploring.

In the present study, it was suggested that altered expression levels of $A B A T$ may participate in the pathogenesis of MDS; therefore, the expression levels of $A B A T$ were detected in patients with MDS and AML, and control individuals. Control patients had immune thrombocytopenia, and were considered suitable controls for MDS. In terms of routine blood examination, MDS and immune thrombocytopenia both present with cytopenia; in addition, MDS is a hemopoietic clonal disease, whereas immune thrombocytopenia is not a clonal disease of the blood system. The results demonstrated that the mRNA expression levels of $A B A T$ were reduced in patients with MDS compared with in the controls. The present findings indicated that reduced $A B A T$ expression in patients with MDS may be associated with high methylation of the $A B A T$ gene. Notably, as the number of bone marrow blasts 
increased, so did the expression levels of $A B A T$. Subjects in the high-risk group exhibited higher $A B A T$ expression compared with in the low-risk group; therefore, it was suggested that high $A B A T$ expression may be used to predict disease progression for patients with MDS. However, in this study, $A B A T$ gene expression was higher in control patients compared with in patients with MDS. Using multivariate analysis, it was demonstrated that the expression of $A B A T$ was not an independent factor for prognosis. Gene expression can be regulated at the DNA and RNA level; therefore, $A B A T$ expression may not be a good predictor for disease progression. However, low expression levels of $A B A T$ have been reported to be associated with poor prognosis in patients with breast cancer and hepatocellular carcinoma (9-11). Disease types and the complexity of disease pathogenesis may be important factors.

In patients with cancer, aberrant hypermethylation in the promoter region often results in reduced gene expression (1). In our previous study, it was hypothesized that $A B A T$ gene hypermethylation led to reduced expression (6). In the present study, when analyzing the expression and methylation levels of $A B A T$ in patients with MDS and AML, the same trend was observed with regards to methylation and mRNA expression. The results of a survival analysis indicated that higher $A B A T$ methylation was associated with poor prognosis in patients. In multivariate analysis, $A B A T$ gene methylation was revealed to be an independent indicator for disease progression. In addition, the methylation degree of $A B A T$ was revealed to be an independent prognostic factor. In AML, an inverse correlation has been detected between gene expression (CCAAT enhancer binding protein $\alpha$ and CCAAT enhancer binding protein $\delta$ ) and methylation (32). In addition to methylation, several other factors influence gene expression, including chromatin remodeling, transcriptional activation from a new transcription start site (33), intragenic DNA methylation (34) and abnormal histone acetylation (35). The exact mechanisms underlying gene regulation require further exploration in patients with MDS.

It has previously been demonstrated that conversion of GABA into SSA and glutamate is catalyzed by GABAT (26). GABAT-derived glutamate is then catabolized by glutamate dehydrogenase into $\alpha$-ketoglutaric acid, which enters the TCA cycle (26). The $A B A T$ gene also participates in the mitochondrial nucleoside salvage pathway. If $A B A T$ gene expression is knocked down and relative activity of GABAT is decreased, DNA depletion of mitochondria occurs (8). Since $A B A T$ is closely associated with the TCA cycle and mitochondrial nucleoside salvage pathway, and the methylation level of $A B A T$ was considered a prognostic indicator for patients with MDS, the biological function of $A B A T$ in leukemia cells was determined, in order to evaluate its involvement in the pathogenesis of MDS.

In the present study, when $A B A T$ was knocked down, the percentage of apoptosis was significantly increased, and the expression levels of apoptosis-associated proteins, including cleaved caspase-3 and Bax, were upregulated. Simultaneously, cell cycle distribution was detected by flow cytometry, and it was revealed that cell cycle progression was blocked in $\mathrm{G}_{1} / \mathrm{S}$ phase in response to $A B A T$ knockdown. Furthermore, the expression levels of associated proteins, including CDK4, CDK6, cyclin D1 and cyclin D3, were decreased. In tumor cells, the CDK/cyclin D-retinoblastoma protein kinase complex regulates $\mathrm{G}_{1} / \mathrm{S}$ transition, and decreased $\mathrm{CDK} /$ cyclin $\mathrm{D}$ activity can result from the low expression of D-type cyclins or CDK4/6 (36). In the present study, knockdown of $A B A T$ gene expression led to reduced $\mathrm{CDK} /$ cyclin $\mathrm{D}$ protein expression and blockage of $\mathrm{G}_{1} / \mathrm{S}$ phase, thus indicating that the $A B A T$ gene may be crucial in the pathogenesis of MDS. Notably, two groups of CDK inhibitors (CDKIs) regulate CDK/cyclin D activity: The INK4 family (notably p16 ${ }^{\text {INK4a }}$ ) and Cip/Kip family (p21 ${ }^{\text {Waf1/Cip1 }}$, p27 and p57) (37). High expression of CDKIs is often associated with inhibition of CDK expression. Correspondingly, cells with low expression of CDK4 and CDK6 frequently exhibit upregulation of antiperiodic proteins p16 ${ }^{\text {INK4a }}$ and p21 $1^{\text {War1/Cipl }}$ (38). In THP-1 cells, p16 expression was similar to that in SKM-1 cells; however, the expression of $\mathrm{p} 21^{\text {Wafl/Cipl }}$ protein was downregulated in response to $A B A T$ knockdown. $\mathrm{p} 21^{\text {Waf1/Cip1 }}$, as a CDKI, is a characterized modulator of p53-induced cell cycle arrest, which is recognized as an important tumor suppressor gene; inactivation of p53 can lead to reduced expression of $\mathrm{p} 21^{\text {Wafl/Cipl }}$ (39). In THP-1 cells, p53 activity should be determined following $A B A T$ knockdown. When these cells were treated with the GABAT inhibitor vigabatrin, cell cycle progression was also blocked at the $\mathrm{G}_{1} / \mathrm{S}$ phase; however, the inhibitor had no effect on cell apoptosis. The present study hypothesized that the role of GABAT in MDS pathogenesis did not work only through enzyme activity. The mechanism in patients with MDS and leukemia cell lines requires further exploration.

In conclusion, the present study revealed that $A B A T$ was highly methylated in patients with MDS. The mRNA expression levels and degree of methylation of $A B A T$ in patients with MDS was dynamically altered with progression of disease. The age of subjects with MDS, hemoglobin levels, WHO classification, marrow blast levels, IPSS cytopenias, karyotypes and risk group, mRNA levels of $A B A T$, and methylation percentages were all associated with OS of patients with MDS, whereas age, marrow blast count and the degree of $A B A T$ methylation were independent factors for the survival of patients with MDS. Biological function analysis revealed that cell apoptosis and cell cycle distribution were closely associated with $A B A T$ gene expression. Future studies should investigate the role of the $A B A T$ gene in the molecular mechanisms in patients with MDS. In the future, molecular inhibitors may be designed that target the TCA cycle, in order to offset the function of the $A B A T$ gene in leukemia, or that can be combined with other inhibitors to provide possible strategies for clinical treatment.

\section{Acknowledgements}

The authors would like to thank Dr Yan Wang (Huashan Hospital, Fudan University) for his operation and analysis of flow cytometry.

\section{Funding}

The present study was supported by grants from The Natural Science Foundation of Shanghai (grant nos. 16ZR1404400 and 17ZR1403600) and The Key Construction Building Subject of Three-year Action Plan of Fourth Round of Public Health Project in Shanghai (grant no. 15GWZK0801). 


\section{Availability of data and materials}

The datasets used and/or analyzed during the current study are available from the corresponding author on reasonable request.

\section{Authors' contributions}

JG and XW designed the experiments. GZ performed and analyzed most of the experiments, and wrote the manuscript. SL and WW collected and analyzed MDS patient blood samples. NL performed some experiments. All authors read and approved the final manuscript.

\section{Ethics approval and consent to participate}

All procedures involving human participants were performed in accordance with the ethical standards of the institutional research committee and with the 1964 Helsinki declaration and its later amendments or comparable ethical standards. The present study was approved by the Ethics Committee of Huashan Hospital, Fudan University (approval no. KY2015-269). Patients provided informed consent.

\section{Patient consent for publication}

Informed consent was obtained from all individual participant included in the study.

\section{Competing interests}

The authors declare that they have no competing interests.

\section{References}

1. del Rey M, O'Hagan K, Dellett M, Aibar S, Colyer HA, Alonso ME, Díez-Campelo M, Armstrong RN, Sharpe DJ, Gutiérrez NC, et al: Genome-wide profiling of methylation identifies novel targets with aberrant hypermethylation and reduced expression in low-risk myelodysplastic syndromes. Leukemia 27: 610-618, 2013.

2. Leone G, Voso MT, Teofili L and Lübbert M: Inhibitors of DNA methylation in the treatment of hematological malignancies and MDS. Clin Immunol 109: 89-102, 2003.

3. Khan $\mathrm{H}$, Vale $\mathrm{C}$, Bhagat $\mathrm{T}$ and Verma A: Role of DNA methylation in the pathogenesis and treatment of myelodysplastic syndromes. Semin Hematol 50: 16-37, 2013.

4. Zhao X, Yang F, Li S, Liu M, Ying S, Jia X and Wang X: CpG island methylator phenotype of myelodysplastic syndrome identified through genome-wide profiling of DNA methylation and gene expression. Br J Haematol 165: 649-658, 2014.

5. Dexheimer GM, Alves J, Reckziegel L, Lazzaretti G and Abujamra AL: DNA methylation events as markers for diagnosis and management of acute myeloid leukemia and myelodysplastic syndrome. Dis Markers 2017: 5472893, 2017.

6. Li N, Chen Q, Gu J, Li S, Zhao G, Wang W, Wang Z and Wang X: Synergistic inhibitory effects of deferasirox in combination with decitabine on leukemia cell lines SKM-1, THP-1, and K-562 Oncotarget 8: 36517-36530, 2017.

7. Schwab C, Yu S, Wong W, McGeer EG and McGeer PL: GAD65, GAD67, and GABAT immunostaining in human brain and apparent GAD65 loss in Alzheimer's disease. J Alzheimers Dis 33: 1073-1088, 2013.

8. Besse A, Wu P, Bruni F, Donti T, Graham BH, Craigen WJ, McFarland R, Moretti P, Lalani S, Scott KL, et al: The GABA transaminase, ABAT, is essential for mitochondrial nucleoside metabolism. Cell Metab 21: 417-427, 2015.
9. Budczies J, Brockmöller SF, Müller BM, Barupal DK, Richter-Ehrenstein C, Kleine-Tebbe A, Griffin JL, Orešič M, Dietel M, Denkert C, et al: Comparative metabolomics of estrogen receptor positive and estrogen receptor negative breast cancer: Alterations in glutamine and beta-alanine metabolism. J Proteomics 94: 279-288, 2013.

10. Jansen MP, Sas L, Sieuwerts AM, Van Cauwenberghe C, Ramirez-Ardila D, Look M, Ruigrok-Ritstier K, Finetti P, Bertucci F, Timmermans MM, et al: Decreased expression of ABAT and STC2 hallmarks ER-positive inflammatory breast cancer and endocrine therapy resistance in advanced disease. Mol Oncol 9: 1218-1233, 2015.

11. Chen P, Wang F, Feng J, Zhou R, Chang Y, Liu J and Zhao Q: Co-expression network analysis identified six hub genes in association with metastasis risk and prognosis in hepatocellular carcinoma. Oncotarget 8: 48948-48958, 2017.

12. Bennett JM: World Health Organization classification of the acute leukemias and myelodysplastic syndrome. Int J Hematol 72: 131-133, 2000.

13. Greenberg P, Cox C, LeBeau MM, Fenaux P, Morel P, Sanz G, Sanz M, Vallespi T, Hamblin T, Oscier D, et al: International scoring system for evaluating prognosis in myelodysplastic syndromes. Blood 89: 2079-2088, 1997.

14. Livak KJ and Schmittgen TD: Analysis of relative gene expression data using real-time quantitative PCR and the 2(-Delta Delta C(T)) method. Methods 25: 402-408, 2001.

15. Besse A, Petersen AK, Hunter JV, Appadurai V, Lalani SR and Bonnen PE: Personalized medicine approach confirms a milder case of ABAT deficiency. Mol Brain 9: 93, 2016.

16. Lin J, Yao DM, Qian J, Wang YL, Han LX, Jiang YW, Fei X, Cen JN and Chen ZX: Methylation status of fragile histidine triad (FHIT) gene and its clinical impact on prognosis of patients with myelodysplastic syndrome. Leuk Res 32: 1541-1545, 2008.

17. Iwai M, Kiyoi H, Ozeki K, Kinoshita T, Emi N, Ohno R and Naoe T: Expression and methylation status of the FHIT gene in acute myeloid leukemia and myelodysplastic syndrome. Leukemia 19: 1367-1375, 2005.

18. Wang $\mathrm{H}$, Wang XQ, Xu XP and Lin GW: ID4 methylation predicts high risk of leukemic transformation in patients with myelodysplastic syndrome. Leuk Res 34: 598-604, 2010.

19. Wu SJ, Yao M, Chou WC, Tang JL, Chen CY, Ko BS, Huang SY, Tsay W, Chen YC, Shen MC, et al: Clinical implications of SOCS1 methylation in myelodysplastic syndrome. Br J Haematol 135: 317-323, 2006.

20. Zhou JD, Lin J, Zhang TJ, Ma JC, Yang L, Wen XM, Guo H, Yang J, Deng ZQ and Qian J: GPX3 methylation in bone marrow predicts adverse prognosis and leukemia transformation in myelodysplastic syndrome. Cancer Med 6: 267-274, 2017.

21. Calvo X, Nomdedeu M, Navarro A, Tejero R, Costa D, Muñoz C, Pereira A, Peña O, Risueño RM, Monzó M, et al: High levels of global DNA methylation are an independent adverse prognostic factor in a series of 90 patients with de novo myelodysplastic syndrome. Leuk Res 38: 874-881, 2014.

22. Tien HF, Tang JH, Tsay W, Liu MC, Lee FY, Wang CH, Chen YC and Shen MC: Methylation of the p15(INK4B) gene in myelodysplastic syndrome: It can be detected early at diagnosis or during disease progression and is highly associated with leukaemic transformation. Br J Haematol 112: 148-154, 2001.

23. Dan C, Chi J and Wang L: Molecular mechanisms of the progression of myelodysplastic syndrome to secondary acute myeloid leukaemia and implication for therapy. Ann Med 47: 209-217, 2015.

24. Woods BA and Levine RL: The role of mutations in epigenetic regulators in myeloid malignancies. Immunol Rev 263: 22-35, 2015.

25. Ben-Menachem E: Mechanism of action of vigabatrin: Correcting misperceptions. Acta Neurol Scand Suppl 192: 5-15, 2011.

26. Maguire SE, Rhoades S, Chen WF, Sengupta A, Yue Z, Lim JC, Mitchell $\mathrm{CH}$, Weljie AM and Sehgal A: Independent effects of gamma-Aminobutyric acid transaminase (GABAT) on metabolic and sleep homeostasis. J Biol Chem 290: 20407-20416, 2015.

27. DiNardo CD, Jabbour E, Ravandi F, Takahashi K, Daver N, Routbort M, Patel KP, Brandt M, Pierce S, Kantarjian H, et al: IDH1 and IDH2 mutations in myelodysplastic syndromes and role in disease progression. Leukemia 30: 980-984, 2016.

28. Louro P, Ramos L, Robalo C, Cancelinha C, Dinis A, Veiga R, Pina R, Rebelo O, Pop A, Diogo L, et al: Phenotyping GABA transaminase deficiency: A case description and literature review. J Inherit Metab Dis 39: 743-747, 2016. 
29. Barnby G, Abbott A, Sykes N, Morris A, Weeks DE, Mott R, Lamb J, Bailey AJ and Monaco AP; International Molecular Genetics Study of Autism Consortium: Candidate-gene screening and association analysis at the autism-susceptibility locus on chromosome 16p: Evidence of association at GRIN2A and ABAT. Am J Hum Genet 76: 950-966, 2005.

30. Jirholt J, Asling B, Hammond P, Davidson G, Knutsson M, Walentinsson A, Jensen JM, Lehmann A, Agreus L and Lagerström-Fermer M: 4-aminobutyrate aminotransferase (ABAT): Genetic and pharmacological evidence for an involvement in gastro esophageal reflux disease. PLoS One 6: e19095, 2011.

31. Wegerer M, Adena S, Pfennig A, Czamara D, Sailer U, Bettecken T, Müller-Myhsok B, Modell S and Ising M: Variants within the GABA transaminase (ABAT) gene region are associated with somatosensory evoked EEG potentials in families at high risk for affective disorders. Psychol Med 43: 1207-1217, 2013 .

32. Musialik E, Bujko M, Kober P, Grygorowicz MA, Libura M, Przestrzelska M, Juszczyński P, Borg K, Florek I, Jakóbczyk M, et al: Comparison of promoter DNA methylation and expression levels of genes encoding CCAAT/enhancer binding proteins in AML patients. Leuk Res 38: 850-856, 2014.

33. Bert SA, Robinson MD, Strbenac D, Statham AL, Song JZ, Hulf T, Sutherland RL, Coolen MW, Stirzaker C and Clark SJ: Regional activation of the cancer genome by long-range epigenetic remodeling. Cancer Cell 23: 9-22, 2013.
34. Lee SM, Choi WY, Lee J and Kim YJ: The regulatory mechanisms of intragenic DNA methylation. Epigenomics 7: 527-531, 2015.

35. Bergman $\mathrm{Y}$ and Cedar H: DNA methylation dynamics in health and disease. Nat Struct Mol Biol 20: 274-281, 2013.

36. Ouzounoglou E, Dionysiou D and Stamatakos GS: Differentiation resistance through altered retinoblastoma protein function in acute lymphoblastic leukemia: In silico modeling of the deregulations in the G1/S restriction point pathway. BMC Syst Biol 10: 23, 2016.

37. Besson A, Dowdy SF and Roberts JM: CDK inhibitors: Cell cycle regulators and beyond. Dev Cell 14: 159-169, 2008.

38. Bonelli P, Tuccillo FM, Borrelli A, Schiattarella A and Buonaguro FM: CDK/CCN and CDKI alterations for cancer prognosis and therapeutic predictivity. BioMed Res Int 2014: 361020, 2014.

39. Davies C, Hogarth LA, Dietrich PA, Bachmann PS, Mackenzie KL, Hall AG and Lock RB: p53-independent epigenetic repression of the p21(WAF1) gene in T-cell acute lymphoblastic leukemia. J Biol Chem 286: 37639-37650, 2011.

This work is licensed under a Creative Commons Attribution-NonCommercial-NoDerivatives 4.0 International (CC BY-NC-ND 4.0) License. 